\title{
THE BRITISH WORLD AND ITS ROLE IN THE RELATIONSHIP BETWEEN NEW ZEALAND AND THE SOUTHERN CONE COUNTRIES OF SOUTH AMERICA, 1820-1914
}

\begin{abstract}
RESUMEN
Este trabajo de investigación se refiere a las poco conocidas relaciones existentes entre Nueva Zelanda y los países del Cono Sur americano entre 1820 y la Primera Guerra Mundial. Aunque encontramos muchos neozelandeses trabajando en las más diversas ocupaciones en toda América Latina, lo que sin duda fue posible gracias a la presencia británica ya establecida, los lazos que se dieron en el Cono Sur fueron intensos. La base de la relación, que en ese entonces parecía ser permanente, fue el movimiento tanto de barcos, mercaderías, personas, animales, plantas, know-how, y tecnología, como de capitales que cruzaban el Pacífico de un lado al otro, más que relaciones entre países propiamente tales.
\end{abstract}

Palabras clave: barcos, comerciantes, comercio, competencia, harina, frutas, emigración, pastoreo, ovejas de raza, extracción de oro, Nueva Zelanda, Cono Sur.

\begin{abstract}
This research article traces the little-known relationship between New Zealand and the Southern Cone countries of South America that existed between 1820 and the First World War. While New Zealanders were found throughout Latin America in many occupations, undoubtedly because of the established British presence in the region, the links with the Southern Cone were particularly extensive. The basis of the relationship, which promised then to be on-going, was the movement of ships, goods, people, animals, plants, know-how, technology and capital across the Pacific, rather than any inter-state relationship.
\end{abstract}

Key words: ships, merchants, trade, competition, flour, fruit, emigration, pastoralism, pedigree sheep, goldmining, New Zealand and the Southern Cone.

Fecha de recepción: agosto de 2009

Fecha de aceptación: mayo de 2010

* PhD in History awared by the University of Auckland. Archaeology North Ltd. Correo electrónico: ntwohill@xtra.co.nz 
The correspondent to the Otago Witness in Argentina wrote in 1906 that New Zealanders were found wherever one went in South America ${ }^{1}$. This observation reflected the fact that during the nineteenth and early twentieth centuries, shipping, trade, people, animals, plants, know-how, technology and capital linked New Zealand and Latin America. Yet, this connection or its characteristics remain a gap in New Zealand historiography, apart from some discrete references to it, even though at one stage this interaction promised an on-going relationship ${ }^{2}$. The relationship that eventuated left a legacy of dispersed but tangible evidence, including the text on a nineteenth-century wooden headboard dedicated to a Chilean buried in the Old Tairua Cemetery on the east coast of the Coromandel Peninsula of the North Island of New Zealand; the name of Cámeron, a settlement situated on the southern shore of Bahía Inútil on Tierra del Fuego, which originated from a New Zealander; and the introduction of the New Zealand Corriedale sheep to South America.

New Zealand's engagement with Latin America arguably stemmed from the strong British presence in the region as Britain dominated Latin America's economic and, to lesser degree, political affairs between the 1820s-1830s and $1914^{3}$. (For language reasons, this study does not focus on Brazil despite evidence of interaction with New Zealand during the period under review). How New Zealanders, "ignorant of language, of the people, and the strange and intricate business methods" came to successfully assimilate in the alien world of Latin America, and in particular in the Southern Cone countries of Chile, Argentina and Uruguay, may be explained by the already established British presence with its associations and networks, as well as the shared British cultural and institutional values ${ }^{4}$. It was as much an interaction among "Britishers". The idea of a common

\footnotetext{
Otago Witness [hereafter $O W]$, Dunedin, 1 August 1906, 8 e.

2 Kenneth Cumberland, “Jimmy Grants' and 'Mihaneres': New Zealand about 1853”, Economic Geography 30:1, Worcester, MA, 1954, 76, 83; J.B. Chapman, Latin America as a Present and Potential Market for New Zealand's Agricultural Produce: A Geographical Survey, MA and Honours thesis, University of Auckland, 1963, i-v, 1; A.H. McLintock, "Expatriates - Biographies, Editor's Note", in McLintock (ed.), The Encyclopedia of New Zealand, Wellington, Government Printer, 1966, I:575, 582; John Bernard Prendergast, "Trade with Central and South America and the Caribbean", in McLintock (ed.), The Encyclopedia of New Zealand, op. cit., III:430; Arthur H. Carman, The Birth of a City, Wellington, Wright and Carman Ltd., 1970, 17; Thomas W. Keeble, Commercial Relations between British Overseas Territories and South America 1806-1914, London, published for the Institute of Latin American Studies [by] Athlone Press, 1970, 46-47; John Kirby, "On the Viability of Small Countries: Uruguay and New Zealand Compared", Journal of Interamerican Studies and World Affairs 17:3, Coral Gables, Florida, 1975, 260-261; David Pheasant, "New Zealand-Latin American Trading Relations: Past, Present and Future", in Roberto G. Rabel (ed.), Latin America in a Changing World Order, Dunedin, University Extension, University of Otago, 1992, 135; Tom Brooking, Lands for the People? The Highland Clearances and the Colonisation of New Zealand. A Biography of John McKenzie, Dunedin, University of Otago Press, 1996, 11, 81, 97, 101, 157, 168, 256-257; John Wilson, "Latin Americans", Te Ara-The Encyclopedia of New Zealand, online, updated 21 September 2007, available at: www.TeAra.govt.nz/NewZealanders/NewZealandPeoples/LatinAmericans/en.

3 Leslie Bethall, "Britain and Latin America in historical perspective", in Victor BulmerThomas (ed.), Britain and Latin America: a changing relationship, Cambridge (England), Cambridge University Press, 1989, 1.

4 G.L. Tacon, Fruit-Markets and Fruitgrowing in South America, Wellington, Government Printer, 1915, 4.
} 
and connected Southern British World, with its efficient network of "people, gossip, connections, ideas and identity", provides an understanding of New Zealand-Southern Cone contact where the transfer into societies with familiar cultural values is of primary interest ${ }^{5}$. Evidence of the Latin American-New Zealand relationship itself can be quite fragmentary and tenuous; however, the British presence remains the common thread in New Zealand's interaction with the Southern Cone between 1820 and 1914.

Latin America played some part in the early history of New Zealand long before the signing of the Treaty of Waitangi between Mãori and the British in 1840. Organized British settlement in New Zealand then intensified the connection with the Chilean port of Valparaíso during the years 1840-1844. A shortage of flour and wheat in New Zealand caused the New Zealand-Valparaíso relationship to be revived during the 1860 s and endure until the end of the nineteenth century. Elsewhere, too, once New Zealand steamships began going to Britain via the east coast of South America, a linkage developed between New Zealand and the Río de la Plata region (the River Plate) and Southern Patagonia from the mid 1880s.

\section{CHILE}

\section{0-1839}

Following Chilean independence in 1818, Valparaíso grew from a colonial backwater to become a regional economic powerhouse. It became the main port of Chile, a waypoint for travellers, and distribution centre and emporium of the west coast of South America whose reach extended to Peru, Bolivia, Ecuador, transAndean Cuyo, Río de la Plata, Central America, Mexico, New England, Europe, India, East Asia, New South Wales and the Pacific Islands. Trade with the maritime nations of the North Atlantic, especially Britain, was seen by the Chilean government as one of the main stimuli to progress, and early official policy encouraged the primacy of Valparaíso by making it an entrepôt in 1820 and free port in 1822.

Meanwhile, immigration had already been stimulated in 1813 by foreigners being granted the same privileges as Chileans after a four-year residence ${ }^{6}$. Among the communities of foreign merchants -American, German, French, Dane, Italianwho established themselves in Valparaíso afterwards as wholesale merchants, traders and commission agents, the British made up the largest and most important. British success at Valparaíso came from certain advantages based on shipping,

5 Carl Bridge and Kent Fedorowich, "Mapping the British World", in C. Bridge and K. Fedorowich (eds.), The British World: Diaspora, Culture and Identity, London, Frank Cass, 2003, 3-8; Kathleen Wilson, The Island Race: Englishness, Empire and Gender in the Eighteenth Century, London and New York, Routledge, 2003, 16.

6 Santiago Lorenzo Schiaffino, "Influencia de los Extranjeros en la Identidad del Porteño, 18201870", Boletín de la Academia Chilena de la Historia 108/109, Santiago, 1998-1999, 439-440. 
world-wide networks and contacts, and the presence of their merchant houses and offices in the port area of Valparaíso. Indeed, while Chilean imports of foreign goods were quite spectacular from 1818 and into the 1820 s, the greater part of the goods was re-exported elsewhere from Valparaíso by British merchants, usually on British ships ${ }^{7}$.

One consequence of this British connection with Valparaíso was that after British annexation in 1840 a number of early British settlers, administrators and travellers in New Zealand had previously served on the South American station or traded, travelled, been involved in diplomacy or had family in Spanish America. Such familiarity may explain why in 1840 some disaffected New Zealand Company settlers at Port Nicholson -called "the Chilians" by Edward Jerningham Wakefield- entertained the idea of emigrating to Chile to take up land as an alternative to staying in New Zealand during the events surrounding Lieutenant Governor William Hobson's proclamation to disband the settlers' Council and the Land Claims Act of Governor Sir George Gipps which threatened to void all land titles in New Zealand not obtained through the Crown ${ }^{8}$. Similarly, the decision by Robert FitzRoy, commander of the Beagle hydrographic survey in the southern part of South America in 1830-1831 and 1832-1835 and governor of New Zealand between 1843 and 1845 , to introduce a low-denominational paper currency (debentures which became legal tender) during 1844 was from having observed the currency's effectiveness in Chile and Brazil ${ }^{9}$.

Also, analogies with South America were used to make the distant New Zealand islands more comprehensible to readers in Britain already familiar with Latin America. Charles Darwin thought, as the Beagle entered the Bay of Islands in 1835, that the landscape resembled "the country a short distance to the Southward of Concepcion in Chili"10. In 1839 the New Zealand Land Company prospectus called the Southern Alps of the South Island "the Andes-like chain

7 Charles W. Centener, "Relaciones comerciales de Gran Bretaña con Chile 1810-1830", Revista Chilena de Historia y Geografía 103, Santiago, 1943, 96-98; Robert G. Albion, "Capital Movement and Transportation: British Shipping and Latin America, 1806-1914", Journal of Economic History 11:4, New York, 1951, 363; Alexander Caldcleugh, Travels in South America during the Years 1819-20-21. Containing an Account of the Present State of Brazil, Buenos Ayres and Chile. Volume 1, London, John Murray, 1825, 358; Peter Schmitmeyer, Travels into Chile over the Andes, In the Years 1820 and 1821, etc., London, Longman, Hurst, Rees, Orme, Brown, \& Green, 1824, 298; Peter Mathias, The First Industrial Nation: an economic history of Britain, 1700-1914, London and New York, Methuen, 1983, 283-284.

8 The name Port Nicholson has been replaced by Wellington Harbour. Edward Jerningham Wakefield was the son of Edward Gibbon Wakefield (who together with the New Zealand Company organized colonization in New Zealand). "Reminiscences of James John Taine, a Wellington and New Zealand Pioneer Settler of 1839", NZMS 785/2, 194, 201, Special Collections, Auckland Public Libraries - Central; New Zealand Journal [hereafter NZJ], London, 5 June 1841, 136; Charles Heaphy, Narrative of a Residence in Various Parts of New Zealand, London, Smith, Elder, 1842, 10; Edward Jerningham Wakefield, Adventure in New Zealand from 1839 to 1844, London, J. Murray, 1845, I:106, 358-359; Alexander Majoribanks, Travels in New Zealand, London, Smith, Elder, 1846, 52.

${ }^{9}$ New-Zealander, Auckland, 31 July 1847, 2 c, d; Robert FitzRoy, Remarks on New Zealand, in February 1846, London, W. \& H. White, 1846, 25-26.

10 Charles Darwin's Beagle Diary, Richard Darwin Keynes (ed.), Cambridge (England) and New York, Cambridge University Press, 1988, 381. 
which formed the back-bone of New Zealand"11. Ernst Dieffenbach, surveyor to the New Zealand Company, wrote to the New Zealand Gazette in 1840 that "we could compare the Western part of this [North] island with the land on the western side of the Andes in America [...]"12. And FitzRoy made a comparison between Switzerland, Norway, Tierra del Fuego and the hill country in the vicinity of Wellington in 1844 for the Colonial Secretary, Lord Stanley ${ }^{13}$.

As important as such resonances were, however, the economic power of Valparaíso counted more for the New Zealand-Latin American link. As part of the exotic and far-flung trade network of Valparaíso were West and East Polynesia. For the New Zealand islands, the trade between Valparaíso and New South Wales was the Pacific exchange which had the most implications. Trading contact between Valparaíso and Sydney had a relatively long history. As early as 1803, the governor of New South Wales, Philip Gidley King, tried to import cattle, alpacas, guanacos and grain from Chile. The first recorded ship to have arrived in Valparaíso from New Zealand was the Surry, on 31 January 1820, en route from Sydney and Hobart, carrying a cargo of general goods destined for London ${ }^{14}$. At least 22 ships broke their voyage from Sydney to Valparaíso to call into New Zealand between 1820 and 1839 - a figure which gives validity to one scholar's assertion that the basis of New Zealand's relationship with Latin America was one of "wind-falls" because of New Zealand's geographical location between Sydney and Valparaíso"

Among the ships that called were a number that came to collect timber at Hauraki and the Hokianga in the North Island - the first cargo of spars taken out of the Hokianga went to Valparaíso on the Providence in 1822 ${ }^{16}$. The St Patrick reportedly made an "immense sum" on the New Zealand spars it took to Valparaíso in $1825^{17}$. However, the casual nature of the timber trade and the fact that only some eight ships arrived in New Zealand waters from Valparaíso, affirm the tenuous nature of the relationship ${ }^{18}$. One explanation why can be found in Captain George Bayly's Sea-Life Sixty Years Ago, in which he writes of the second voyage

11 British Parliamentary Papers [hereafter BPP], The New Zealand Land Company, Form of Application for Shares, Volume 3, Colonies New Zealand, 30.

12 NZJ, 27 February 1841, 53.

$13 B P P$, Dispatch from Governor FitzRoy to Lord Stanley, 15 April 1844, 4, 22-23.

14 Eugenio Pereira Salas, "Las primeras relaciones entre Chile y Australia", Boletín de la Academia Chilena de la Historia 53, Santiago, 1955, 24, 29.

15 Keeble, op. cit., 46-47.

16 R.A.A. Sherrin, "From Earliest Times to 1840", in Thomson W. Leys (ed.), The Early History of New Zealand, Brett's Historical Series, Auckland, H. Brett, 1890, 287; John O'C. Ross, William Stewart, Canberra, Roebuck, 1989, 123-124.

17 Captain George Bayly, Sea-Life Sixty Years Ago, London, Kegan Paul, Trench and Co., 1885, 92; J.W. Davidson, Peter Dillon of Vanikoro: chevalier of the South Seas, O.H.K. Spate (ed.), Melbourne, Oxford University Press, 1975, 67.

18 Before arriving at his new mission station in New Zealand from Chile, Bishop Pompallier wrote he had to spend several months in Valparaíso because it was rare "in those days [1837] to find any ships sailing for the South Pacific", Rt. Rev. Jean Baptiste François Pompallier, Early History of the Catholic Church in Oceania, with introduction by the Rt. Rev. John Edmund Luck, Bishop of Auckland, Auckland, H. Brett, 1888, 13. 
made by the St Patrick from Valparaíso in 1825 to Wairoa in the Hauraki Gulf to load spars for Calcutta. The ship entered a Mãori world that was still engaged in tribal life, inter-tribal war, slavery, tapu, utu (revenge), mana and powerful chiefs, and where misunderstanding, cheating and the threat of violence between the ship's crew and Mãori were always present. Therefore Polynesia was a frontier that represented venture and risk to merchants and traders and their ships, whereas Sydney in contrast promised a more stable trade in wheat ${ }^{19}$.

The reputation of Valparaíso as being the best market on the west coast of South America and its proximity to Cape Horn for ships entering or leaving the Pacific saw it become a haven and shipyard during the 1820 s with carpenters, shipwrights, sail makers and ship's husbands to repair and fit out vessels. It was a destination and centre for foreign merchants and traders, ships" captains, naval squadrons, scientists, literati, missionaries, travellers, migrants, refugees and deserters $^{20}$. Also in the midst of this activity were Hinaki and another Hauraki Mãori chief (whose name is not known) who had been taken on board the Calder at the Bay of Islands in 1823, during the inter-tribal Musket Wars, to obtain muskets and gunpowder in South America in return for New Zealand timber ${ }^{21}$. And Thomas Kendall, a missionary with the Church Missionary Society and one of the best known early Europeans in New Zealand, left the Bay of Islands with his family in 1825 for Valparaíso. Kendall stayed for two years as clergyman to the British community and as a school master to the children of the British consul ${ }^{22}$. Kendall was on the subscription list to the Protestant Cemetery on Cerro Panteón, alongside well-known British merchants in Valparaíso. In 1827 he gave $\$ 17$ and two reales towards the cemetery, and consecrated $\mathrm{it}^{23}$. There were trans-Pacific crossings the other way too, like Miguel Zenteno's, son of José Ignacio Zenteno del Pozo y Silva and governor of Valparaíso, who was on board the St Patrick at Wairoa. And John Cross, who was born in Valparaíso, and who signed on to Captain William Hingston's whaler, the Mary Ann, at the Bay of Islands in $1837^{24}$. This movement of ships and people across the Pacific brought New Zealand within the periphery of

19 Pereira Salas, op. cit., 26; also Thomas M. Bader, "Before the Gold Fleets: Trade and Relations between Chile and Australia, 1830-1848", Journal of Latin American Studies 6:1, LondonNew York, 1974, 35-58.

20 John Rector, "Transformaciones comerciales producidas por la independencia de Chile", Revista Chilena de Historia y Geografía 144, Santiago, 1976, 62-80; Gilberto Harris Bucher, "La marinería desertora chilena y extranjera en Valparaíso: su importancia en la cultura marítima porteña del siglo XIX”, Boletín de la Academia Chilena de la Historia 110, Santiago, 2000-2001, 276; Luis Mizón, Claudio Gay y la formación de la identidad cultural chilena, Santiago de Chile, Editorial Universitaria, 2001, 41; Baldomero Estrada Turra, "Poblamiento e Inmigración en una Ciudad-Puerto: Valparaíso 1820-1920”, in Baldomero Estrada, Eduardo Cavieres, Karin Schmutzer and Luz María Méndez (eds.), Valparaíso: Sociedad y Economía en el Siglo XIX, Valparaíso, Instituto de Historia, Facultad de Filosofía y Educación, Universidad Católica de Valparaíso, 2002, 22.

21 Davidson, op. cit., 80; Bayly, op . cit., 129.

22 Judith Binney, The Legacy of Guilt: A Life of Thomas Kendall, revised edition, Wellington, Bridget Williams Books, 2005, 162, 179.

23 Ana María Ojeda Fernández, El Cerro Panteón y sus Cementerios $N^{o} 1, N^{o} 2$ y Disidentes, Valparaíso, Ilustre Municipalidad de Valparaíso, no date, 31-32.

24 Bayly, op. cit., 110-111; William George Cornelius Hingston Papers, Muster Roll, MS-CopyMicro 0204 (copy of MS-Papers-0043-50), folder 5, Alexander Turnbull Library, Wellington. 
Valparaíso's awareness: in 1828 El Mercurio de Valparaíso referred to a wild flax (cáñamo) growing around Valparaíso "like the one of New Zealand"25.

Communications networks in Latin America had an integral part to play in the New Zealand Company's original plans for settlement in New Zealand, therefore underlining the importance of Latin America in the founding of European settlement in New Zealand. Before any New Zealand Company settler sailed out, the creation of the Royal Mail Steam Packet Company in 1839 and the Pacific Steam Navigation Company in 1840 had dominated the maritime contacts on the west coast of South America and, as historian Robert G. Albion observes, set the pattern for its whole economic development ${ }^{26}$. The new services established by the Royal Mail Steam Packet Company in the Caribbean and the Pacific Steam Navigation Company between Valparaíso and Callao enabled the New Zealand Company to conceive of a route "which would make New Zealand the closest of the Australasian colonies to England and not the furtherest", at the very time when the potential success of the New Zealand Company's scheme depended on rapid communication between New Zealand and Britain. Rapid communications would mean greater prosperity and faster colonization ${ }^{27}$. In 1839 , therefore, the New Zealand Company became committed to establishing communications between its settlement at Port Nicholson and the west coast of South America with a regular packet service 28 . The sailing of steamers between New Zealand and South America was widely anticipated. New Zealand Company surveyor Charles Heaphy believed the existence of coal on the Chatham Islands would be of particular importance if a line of steamers were going to be established between New Zealand and South America $^{29}$.

In 1840 a similar vision existed in Valparaíso also - where Valparaíso would be linked with Australasia, the East Indies and Cochin-China. Amidst the euphoria of the new Pacific Steam Navigation Company service on the west coast, an unnamed London company (possibly the Pacific Steam Navigation Company) proposed establishing a steamer link between Chile and New South Wales. In September 1840 merchant house Naylor, Boardman y Compañía advertised $£ 50$ shares in the venture ${ }^{30}$.

The promise of a regular shipping link between New Zealand and Britain via the west coast of South America therefore brought the New Zealand islands closer into the British order. This development between New Zealand and Latin America was different from 1820 when the extent of European influence in New Zealand was dispersed among trading, mission and whaling stations and one town, Kororãreka, in the Bay of Islands, primarily a whaling base. Contact between Latin America and New Zealand remained intermittent. There was no particular basis for

25 El Mercurio de Valparaíso [hereafter EMV], 7 de junio de 1828, 1 a.

26 Albion, op. cit., 365.

27 BPP, Correspondence Respecting the Colony of New Zealand, 3, 1835-1842, 25; NZJ, 27 May $1843,123$.

28 Idem.

29 Heaphy, op. cit., 124.

$30 E M V, 21$ de septiembre de 1840,4 a, b. 
Valparaíso to conduct trade in pre-colonial New Zealand. With British annexation of New Zealand, however, Latin America became important to New Zealand, by bringing an increase in shipping and business between New Zealand and Valparaíso.

\section{$1840-1849$}

In the early $1840 \mathrm{~s}$, the different levels of development of the New Zealand settlements and Valparaíso were unmistakable. All of New Zealand's colonization was concentrated on the littorals of Cook Strait at Wellington, Wanganui, Nelson and New Plymouth and at Auckland on the Waitematã Harbour. Settlement was characterized by "the instant township"; "beach-heads" placed on the shoreline or riverbank and each populated with between 1,000 and 4,000 colonists within the first two years of settlement ${ }^{31}$. Across the Pacific, meanwhile, Valparaíso had grown and developed since the mid 1830s -when it lacked amenities, conveniences and public security- and had given Chile a reputation for progressive prosperity throughout the world 32 . By 1842 , with a population of some 40,000 , the city had a sophisticated and contemporary appearance beyond the narrow and dirty streets of the port area ${ }^{33}$. The city's supremacy in the southeast Pacific had also been assured after Chile had successfully defeated the Peru-Bolivian Confederation in a war (1836-1839) fought partly to protect the position of Valparaíso. The Pacific Steam Navigation Company's run between Valparaíso and Callao was extended to Panama in 1845 to connect with the Royal Mail Steam Packet Company steamers between Panama and Southampton. These connections meant greater regional interdependence for Valparaíso.

New Zealand, mooted at times in the late eighteenth century as a platform for British incursions into and trade with Spanish America, was regarded by nineteenth-century British strategists and capitalists as a nodal point on trade routes to more lucrative opportunities in the tropical world ${ }^{34}$. The New Zealand Journal, the New Zealand Company's organ in London, saw the sequence of Port

31 James Belich, Making Peoples: a history of the New Zealanders: from Polynesian settlement to the end of the nineteenth century, London and Auckland, Allen Lane and Penguin Press, 1996, 188; Jim McAloon, "Resource Frontiers, Environment, and Settler Capitalism 1769-1860", in Eric Pawson and Tom Brooking (eds.), Environmental Histories of New Zealand, Auckland, Oxford University Press, 2002, 61 .

32 Roberto Hernández Cornejo, cited in Jay Monaghan, Chile, Peru, and the California Gold Rush of 1849, Berkeley, University of California Press, 1973, 178; Jay Kinsbruner, Diego Portales: Interpretative Essays on the Man and Times, The Hague, Nijhoff, 1967, 39.

33 “Journal of Henry Weekes 1840-1842", MS-0845, 76, Hocken Library, Dunedin; Henry Gabriel Swainson, "Letters mainly to his sister, while serving on HMS Havannah and HMS James Watt 1847-1858", MS-2097, 2, Alexander Turnbull Library, Wellington.

34 Alan Frost, The Global Reach of Empire: Britain's Maritime Expansion in the Indian and Pacific Oceans, 1764-1815, Carlton (Victoria), Miegunyah Press, 2003, 76, 97-98; and "The Spanish Yoke: British Schemes to Revolutionise Spanish America, 1739-1807", in Alan Frost and Jane Samson (eds.), Essays in Honour of Glyndwr Williams, Melbourne, Melbourne University Press, 1999, 43-44; Robert J. King (translator), The Secret History of the Convict Colony: Alexandro Malaspina's Report on the British Settlement of New South Wales, Sydney, Allen and Unwin, 1990, 26-27; Donald Denoon, "Understanding Settler Societies", Historical Studies 18:73, Melbourne, 1979, 513. 
Nicholson-Valparaíso-Panama-England as "a chain of communication" in $1841^{35}$. Robert FitzRoy, after he left, understood New Zealand's role to be an entrepôt when he wrote that its geographical position had the facility with which ships could sail between it and South America, and therefore was one factor in securing New Zealand's future ${ }^{36}$. More than had been the case before 1840 , New Zealand and Valparaíso were connected by ships going from New Zealand to Valparaíso to load for Britain. Sir Robert Stout, former New Zealand Premier, noted in 1908 that the usual route to Britain had been via Valparaíso ${ }^{37}$. Edward Jerningham Wakefield stayed five weeks in Valparaíso and the neighbouring district in 1844 on his return to England. As well, Dr Henry Weekes, surgeon-superintendent on the Plymouth Company's ship William Bryan; Samuel Hodgkinson, surgeonsuperintendent on the New Zealand Company's ship Bombay and later owner of the Mount Fairfax station in Southland; Charles Kettle, a New Zealand Company surveyor; Thomas McDonnell, Hokianga timber trader and official Additional British Resident; William Brodie, author and resident in New Zealand until 1844; and Willoughby Shortland, Administrator and Colonial Secretary of New Zealand in 1842-1843, all returned to Britain via Valparaíso ${ }^{38}$.

Contemporaries did not consider Valparaíso to be far. In 1840 Valparaíso was about 50 days' distance by sailing ship from Port Nicholson ${ }^{39}$. For the editor of the newspaper New-Zealander and writer, Charles Terry, Spanish America in 1842 was "not far distant" for the purposes of trade ${ }^{40}$. Similarly, several witnesses giving evidence in 1844 at the Select Committee's enquiry "into the State of the Colony of New Zealand and into the Proceedings of the New Zealand Company" referred to New Zealand's proximity to South America ${ }^{41}$. And the New-Zealander mused in 1845 that a map showed "the easy communication existing between New Zealand and the western coast of South America: by going in the westerly winds, and returning to the south-east trade wind" 42 .

Colonists in New Zealand were looking in the direction of South America for possible markets. Valparaíso, with its established British community and as the consummate entrepôt, offered potential and accessible markets with its own network

35 NZJ, 13 March 1841, 117.

36 FitzRoy, op. cit., 25-27.

37 Frank J. Broeze, Mr Brooks and the Australian Trade: Imperial Business in the Nineteenth Century, Carlton (Victoria), Melbourne University Press, 1993, 143; Edward Jerningham Wakefield, Adventure in New Zealand from 1839 to 1844, Sir Robert Stout (ed.), Christchurch, Whitcombe and Tombs, 1908, xviii.

38 Wakefield, Adventure in New Zealand from 1839 to 1844, op. cit., II:530; James Rutherford and W.H. Skinner, The Establishment of the New Plymouth Settlement in New Zealand 1841-1843, New Plymouth, Avery \& Son, 1940, 104, 115; BPP, Minutes of Evidence Taken Before Select Committee on New Zealand, 2, 6; Walter Brodie, Remarks on the Past and Present State of New Zealand, London, Whittaker and Co., 1845, 106; NZJ, 15 April 1843, 87; Southland Times, Invercargill, 19 November 1932, $2 \mathrm{~d}$.

39 NZJ, 7 March 1840, 34.

40 Charles Terry, New Zealand, Its Advantages and Prospects, as a British Colony, London, T. and W. Boome, 1842, 261.

41 Angus Ross, New Zealand Aspirations in the Pacific in the Nineteenth Century, Oxford, Clarendon Press, 1964, 7-8.

42 New-Zealander, 21 June 1845, 2 c. 
of coastal and interior connections. The New Zealand Company had vaguely envisaged that the economy of its settlements in New Zealand would be founded on "mixed farming on the English model, supplying the local, Australian and British markets, mainly with grain, and supplemented by commerce based on the Mãori trade and the Old New Zealand extractive industries"43. However, development was slow. As attention turned outward, therefore, timber for masts for large schooners, firewood, dried fish, rope and coal were all seen as exports to South America as the new colony was scouting for products to trade ${ }^{44}$. The potential was there: in 1844 Captain Nelson of the Bangalore took a quantity of whapuka, or rock cod, from Auckland and found a ready market in Valparaíso, selling it at seven pence a pound ${ }^{45}$. Hams, salt butter, rope and beer were thought of as products which could be sent to South America from a "colony of agriculturists" more directly than from Britain $^{46}$. And in return, it was suggested that New Zealand could take cocoa from Guayaquil (at the time cocoa followed a circuitous route around Cape Horn to England and from there to Sydney before arriving in New Zealand); salt from Salinas in Peru; and South American tanbark ${ }^{47}$.

Meanwhile, for merchants and traders in Valparaíso, links with New Zealand continued. In 1842 Naylor, Boardman y Oxley had the New-York Packet take rigging and equipment back to Valparaíso stripped from the Chilean ship Sourabaya, condemned in the Bay of Islands as being unseaworthy ${ }^{48}$. The annexation of New Zealand promised new business opportunities for the merchants and traders in Valparaíso. In the early 1840s, therefore, a syndicate from South America sent a representative with $£ 5,000$ cash to purchase land in New Zealand but the plan fell through in the end because of government land policies, and the representative returned to South America. Even then, a possible connection to the South American syndicate, Thomas Morris McLaughlin, left Chile in 1845 and purchased 1,152 hectares of land in the Auckland district at Wiri. But to be more precise, New Zealand was seen in Valparaíso as more of a stepping-stone to the bigger commercial prizes of the Australian colonies and Asia ${ }^{49}$.

In the end, though, the real catalyst to interaction between the new New Zealand settlements and Valparaíso was the trade in flour and wheat between New South Wales and Chile. During 1840 there was a rapid increase in trade between New

43 Belich, Making Peoples, op. cit., 340-341.

44 Auckland Chronicle and New Zealand Colonist, Auckland, 21 December 1842, 46 b; New Zealand Gazette, Wellington, copied in NZJ, 13 April 1844, 443; Heaphy, op. cit., 49; S.M. Martin, New Zealand; In a Series of Letters, London, Simmonds and Ward, 1845, 236.

45 NZJ, 2 June $1849,125$.

46 New-Zealander, 21 June 1845, 2 c; Edward Jerningham Wakefield, The Handbook for New Zealand: Consisting of the Most Recent Information Compiled for the Use of Intending Colonists by A Late Magistrate of the Colony, who Resided There during Four Years, London, J.W. Parker and Savill and Edwards, 1848, 182.

47 New-Zealander, 21 June 1845, 2 c; Terry, op. cit., 259.

48 Robert Burrows, Extracts from a Diary kept by the Rev. R. Burrows during Heke's War in the North in 1845, Auckland, Upton, 1886, 4; EMV, 30 de julio de 1842, 3 c.

49 Martin, op. cit.; OW, 29 June 1888, 7c; Peter Cross (ed.), New Zealand Agriculture: A Story of the Past 150 Years, Auckland, New Zealand Rural Press, 1990, 53; Gaceta del Comercio [hereafter GdelC], Valparaíso, 13 de mayo de 1842,1 a, b, c, 2 a. 
South Wales and Chile, principally in flour and wheat ${ }^{50}$. By then, flour and wheat were products long exported by Chile. In the colonial era, Chile had exported cereals to Peru and Argentina, and the trade continued during disruption caused by independence and civil wars ${ }^{51}$. Following the battle of Lircay in 1830 , the conservatives, dominated by Diego Portales Palazuelos and Manuel Rengifo Cárdenas, began to restore Chile's economy, and not just through their policies for Valparaíso: Chile's transition to being an orderly and economically progressive nation was also based on mining and agriculture ${ }^{52}$. And in agriculture, there was a desire to increase wheat output and export it particularly to the traditional market of Peru to revive the public treasury. Cattle ranches began to grow crops and the raising of stock became less important ${ }^{53}$. Because the Peruvians placed a high tariff on Chilean flour during the 1830s and 1840s, however, flour had to be shipped to alternative markets at the Río de la Plata, New South Wales and the Pacific Islands ${ }^{54}$.

The British settlements in New Zealand thus offered another opportunity for Chilean flour and wheat. Chilean flour obtained from the Morley and the Heron at Wellington in December 1840 caused the local price of flour to drop. And while the sale of some 800 barrels of New Zealand Company flour came almost to a standstill, William Wakefield, Principal Agent for the New Zealand Company in New Zealand, said he was "happy" about the reduction in the high prices of flour ${ }^{55}$. This event alerted Wellington merchants to the advantages of trading with Valparaíso, where cheaper and good quality flour could be bought directly instead of from middlemen in Australia ${ }^{56}$. A scarcity of grain in New South Wales since the late 1830s, however, had opened the New Zealand settlements to exploitation by merchants: flour shipped from New South Wales and Tasmania was made more expensive by merchants importing wheat from Chile and then re-exporting it to New Zealand with further costs of milling, commission and freight added on to $\mathrm{it}^{57}$. Certain people in Wellington therefore took the initiative to beat the high price of flour. Their intention was to deal directly with merchants in Valparaíso, sending dressed timber in return for flour ${ }^{58}$. In October 1842, having been sent to Valparaíso to obtain a cargo of flour, the 120-ton brigantine Cheerful sailed into Wellington with 140 tons of "excellent quality" flour, and was the first vessel to leave Port Nicholson for the sole

50 John Macgregor, The Progress of America: From the Discovery by Columbus to the Year 1846, London, Whittaker and Co., 1847, vol. 1. The figures which Macgregor shows are that in 1839, 281 tons of cargo left Talcahuano and 724 tons from Valparaíso for Australia, whereas in 1840 cargoes jumped to 1,687 tons from Talcahuano and 4,701 tons from Valparaíso, 1111.

51 Sergio Sepúlveda, El Trigo Chileno en el Mercado Mundial: ensayo de geografía histórica, Santiago de Chile, Editorial Universitaria, 1959, 31-33.

52 Bader, op . cit., 42-43.

53 Sepúlveda, op. cit., 34-35; Historia Didáctica de Chile Crono-Antológica, Santiago, Ediciones Occidente, 1996, 311.

54 Arnold J. Bauer, "Expansión Economía en una Sociedad Tradicional: Chile Central en el Siglo XIX”, Historia 9, Santiago, 1970, 150; Bader, op. cit., 42-43.

55 New Zealand Gazette and Britannia Spectator, Wellington, 5 December 1840, 2 b; NZJ, 22 May 1841, 126; Wakefield, Adventure in New Zealand, op. cit., I:419.

56 NZJ, 27 May 1843, 124.

57 New Zealand Colonist and Port Nicholson Advertiser, Wellington, 2 August 1842, 2 c, d.

58 GdelC, 17 de marzo de 1843, 3 a, b. 
purpose of returning with a cargo of flour ${ }^{59}$. While it lasted from 1842 to 1844 , the flour trade with Valparaíso boosted mercantile activity in Wellington. Edward Jerningham Wakefield wrote that " $[\mathrm{t}]$ he shipping was exceedingly busy about this time. Vessels direct from Valparaiso with flour, one from Manilla with tea, sugar, and cigars, and several with cattle from Sydney, gave the anchorage and the wharfs a busy appearance" 60 . The Church Missionary Society schooner Columbine carried Chilean flour also in the stores it took from Wellington around the New Zealand coast to missionaries and their families ${ }^{61}$. It was anticipated that shipping would become more routine between Wellington and Valparaíso, and that ships would be adapted to become faster. The Brougham and Nelson were described as "regular traders" between both ports by one contemporary in a letter written to England ${ }^{62}$. A few years later, based on what he saw during this time, Wakefield would advise intending colonists to New Zealand to learn Spanish because "the trade and communications" between New Zealand and South America and the Philippines "is constantly increasing" ${ }^{3}$. Importantly, though, Wellington was by now well provisioned and everything was becoming cheaper ${ }^{64}$. The price of bread became "reasonable" on account of the cheaper Chilean flour and wheat, although William Swainson found such imports made it hardly worth his while growing wheat on his Hutt farm in $1844^{65}$. And apart from flour, a wide range of merchandise, fruit, animals and alfalfa seed (together with South American weeds mixed up with it) were brought from Valparaíso also ${ }^{66}$. George Duppa, a Nelson settler and son of a director of the New Zealand Company, for example imported grain, potatoes, ploughs, carts, farm tools and bullocks (including their handlers, one of whom was Ben Crisp) from Valparaíso. In short, Valparaíso together with Australia, Manila and Lima were thought to be "within easy reach" and markets for produce and suppliers of "the necessaries and luxuries of life" 67 .

59 New Zealand Gazette and Wellington Spectator [hereafter NZG\&WS], Port Nicholson, 26 October $1842,2 \mathrm{c}$

60 Wakefield, Adventure in New Zealand, op. cit., II:308-309.

61 James West Stack, Early Maoriland Adventures, A.H. Reed (ed.), London, Oxford University Press and Dunedin, A. H. and A. W. Reed, 1937, 67.

62 The Times, London, 20 September 1843, 6 b.

63 Wakefield, The Handbook for New Zealand, op. cit., 438.

64 The Times, 20 September 1843, 6 b.

65 W. Pratt, Colonial Experiences, or Incidents and Reminiscences of the Thirty-Four Years in New Zealand by an Old Colonist, London, 1877 [Facsimile edition, Christchurch, Kiwi Publishers, 1997], 20; William Swainson, Family Letters and Diaries 1808-1855: Final Destiny New Zealand, Palmerston North, G. Swainson, 1992, 100.

66 New Zealand Advertiser and Bay of Islands Gazette, Kororãreka, 24 September 1840, 4 c; NZG\&WS, 5 December 1840, 1 c; 19 December 1840, 1 c; New Zealand Colonist and Port Nicholson Advertiser, 6 September 1842, 3 d; 27 January 1843, 2 c; 30 May 1843, 2 b; NZJ, 27 May 1843, 124; Southern Cross, Auckland, 29 July 1843, 3 a; Nelson Examiner and New Zealand Chronicle, Nelson, 9 May 1846, 39 a; Wakefield, The Handbook for New Zealand, op. cit., 152, 450; J.H. Wallace, "From 1840 to 1845 ", in Leys (ed.), op. cit., 520, 673; Wakefield, Adventure in New Zealand, op. cit., II:494; Stack, op. cit., 40; C.B. Brereton, Vanguard of the South: Nelson, New Zealand, Wellington, Reed, 1952, 183; Alison Drummond (ed.), “Tool-Box and Ploughs: Sarah Higgins of Nelson, 1842", Married and Gone to New Zealand, Hamilton and Oxford, Paul's Book Arcade and Oxford University Press, $1960,86,89$.

67 New Zealand Gazzette, Wellington, copied in NZJ, 13 April 1844, 443. 
One merchant house at the centre of this trans-Pacific business was Ridgway, Guyton and Earp (later Ridgway, Guyton and Company), merchants, shipping agents and auctioneers located on the Te Aro foreshore in Wellington, a firm that had ties with Ridgway, Faranger y Compañía in Valparaíso and Ridgway and Company in London. This connection placed the Wellington firm to the forefront, keeping the public informed on matters relating to South America in the newspapers, while in Valparaíso Ridgway, Faranger y Compañía acted as agents for the New Zealand Company's vessel $\mathrm{Cuba}^{68}$.

Had a regular shipping connection existed between New Zealand and Valparaíso -as the New Zealand Company visualized- the relationship between them may have taken a step forward. In the event, though, the company's vision of a routine link with Valparaíso faded. The idea of a steamer service was replaced with one of four sailing ships, and then the idea of sailing ships fell out of favour after they were thought to have taken too long in making the WellingtonValparaíso-Wellington crossing ${ }^{69}$ Also, there were factors at play by then which caused the New Zealand Company to lose its resolve on the whole question of fast communications between New Zealand and Britain via South America, including a new mail service to Britain via Bombay and Suez ${ }^{70}$.

In the final analysis, the New Zealand Company's limiting position on the matter of communications between Britain and New Zealand was lack of capital. In an era of world economic stagnation, sometimes called "The Hungry Forties", the consequence of sluggish New Zealand land sales in London and a loss of interest in emigration, and near insolvency in late 1843 once news of the first clash between Mãori and European settlers broke out in England, the so-called Wairau Affray, all had a flow-on effect for its settlers in New Zealand as did the slow pace of development of the New Zealand settlements ${ }^{71}$. All of the New Zealand Company settlements were in a shaky position, and the situation was not much better in Auckland either. Working people, who could do so, therefore began to leave New Zealand, with some going to Valparaíso. When the New Zealand settlements were in crisis, Valparaíso was still an important urban and port centre in the Pacific region - and which, moreover, promised employment following an extensive fire which destroyed half the city in $1843^{72}$. This combination of factors gave rise to a classic push-pull effect.

Some 242 colonists left New Zealand for Valparaíso during 1843 and 1844 and in spite of a ferocious campaign by newspapers playing on ancient prejudices and stereotypes to dissuade the emigrants from leaving New Zealand. Among the emigrating colonists were John Ferguson, Robert Duncan, David White, Andrew

68 "Reminiscences of James John Taine", op. cit., 162-163; EMV, 10 de diciembre de 1841, 3 b; GdelC, 1 de marzo de 1842, 4 a, 16 de marzo de 1842, 2 b; Bay of Islands Observer, Kororāreka, 20 October 1842, 3 a, b; NZG\&WS, 28 January 1843,3 a.

69 NZJ, 8 May $1841,114-115 ; 8$ January 1842,2 ; NZG\&WS, 11 September 1841,3 b, c.

70 NZJ, 8 January $1842,2$.

71 Philip Temple, A Sort of Conscience: The Wakefields, Auckland, University of Auckland Press, 2002, 374 .

72 Southern Cross, 29 July 1843, 3 a. 
Hopack and W. Hood, all young carpenters, single or with families, who arrived in Valparaíso on the Brougham in December $1843^{73}$. Observing this phenomenon, the Honourable Constantine Dillon remarked in April 1844 that "many" had gone from Nelson to Valparaíso ${ }^{74}$. And in Valparaíso the influx was impressive enough for the clerk to make a note in the port's shipping register between October 1843 and March 1844 of the number of immigrants arriving from New Zealand ${ }^{75}$. While the migrants may have had to run the gauntlet in New Zealand, their reception in Valparaíso was, however, welcoming.

Chile had been seeking immigrants since independence, even though independence had itself opened Chile up to an influx of foreigners ${ }^{76}$. Even in the 1840s there was still disquiet over the country's small European population and a desire to consolidate the republic and assert its sovereignty. Immigrants were seen as the best means of bringing about the political and economic development of the country, and would populate and provide labour in the under-populated regions of Chile ${ }^{77}$. Ideally, too, they would be northern Europeans, who were valued highly for their level of technological development and enterprise. It was thought that the presence of the hardest-working artisans and agriculturalists and their eventual inter-marriage with Chileans would improve the race and their labour would give value to land not occupied and worked by Chileans ${ }^{78}$.

Assistance given in Valparaíso to the British immigrants (as the immigrants from New Zealand and Australia, where a similar outflow was taking place, were perceived) was generous - they usually arrived possessing no more than a few shillings or what they stood in. The provincial governor, Joaquín Prieto, arranged for the immigrants' accommodation in two forts, the provision of their food and firewood, and an official commission to find out more about them, while a subscription was organized and a

73 This total is a compilation from different sources: Registros Navieros, Entradas, Valparaíso, 1830-1844, 1843, octubre 10-1844, junio 18, Biblioteca Pública Santiago Severín, Valparaíso; Joaquín Prieto al Señor Ministro de Estado en el Departamento del Interior, P.2432, enero 25 de 1844, Volumen 212, Correspondencia e Informes, 1844-1846, Ministerio del Interior, Archivo Nacional de Chile, Santiago de Chile; Relación de los individuos emigrados de Sydney y Nueva Holanda con expresión de los Nombres, Edad, Estado, Patria y Profesión, e igualmente los nombres de los buques en que estos han llegado, P.2436, no date, Volumen 212, Correspondencia e Informes, 1844-1846, Ministerio del Interior, Archivo Nacional de Chile, Santiago de Chile; Southern Cross, 10 February 1844, 3 a; Ruth M. Allan, Nelson: A History of Early Settlement, Wellington, Reed, 1965, 357. However, this total is unreliable. For instance, the number of men, women and children who left Nelson on the Christiana for Valparaíso in February 1844 was put indefinitely at "about 40", Fox, 27 January 1844, New Zealand Company papers 3/14, 27-28, cited in R. Allan, op . cit.

74 The Dillon Letters, C.A. Sharp (ed.), Wellington, Reed, 1954, 37.

75 Registros Navieros, Entradas, Valparaíso, 1830-1844, 10 de octubre de 1843, 3 de diciembre de 1843, 28 de diciembre de 1843, 30 de diciembre de 1843, 27 de marzo de 1844, 28 de marzo de 1844.

76 Ricardo Couyoumdjian Bergamali and Antonia Rebolledo Hernández, "Bibliografía sobre el proceso inmigratorio en Chile, desde la independencia hasta 1930", Hernán Silva (coord.), Bibliografía sobre el impacto del proceso inmigratorio masivo en el Cono Sur de América, México, Instituto Panamericano de Geografía e Historia, 1984, I:121; Harris Bucher, "La marinería desertora", op. cit., 275-289; Francisco Frías Valenzuela, Manual de Historia de Chile, Santiago, Zig-Zag, 1993, 286.

77 Daniela Mohor, "Historias de inmigrantes", El Sábado, Santiago, No 325, 11 de diciembre de $2004,26$.

78 Carmen Norambuena, cited in Mohor, op. cit.; Couyoumdjian and Rebolledo, op. cit.; Historia Didáctica de Chile Crono-Antológica, op. cit., 332. 
society of Valparaíso ladies clothed women and children immigrants ${ }^{79}$. The Valparaiso English Mercury saw the arrival of the immigrants as a result of false representations, but nonetheless appealed to the English community to help fellow Englishmen and praised the government for taking care of the immigrants "in their hour of need" 80 . At the end of February 1844, El Mercurio reported that almost all immigrants from Australasia were working, through the zealous help of certain citizens, business people and charities ${ }^{81}$. However, this initial enthusiasm quickly cooled after an offer by the Chilean government to relocate British immigrants to the southern part of Chile was turned down by some of them, who cited fear of hostile Indian attacks. In response the Valparaiso English Mercury called for the formation of a committee to visit families and explain the government's offer ${ }^{82}$. The new mood was not helped by rumours that many more immigrants were expected to arrive from Australia and New Zealand to an already populous Valparaíso, speaking their own language and bringing different ways, working in unneeded occupations and likely to be reliant on charity. And a letter written by A. Polack, published in the Sydney Morning Herald and copied in El Mercurio in February 1844, portraying Chile as behind the times and poor, aroused resentment in Valparaíso ${ }^{83}$. Nevertheless, Australasian immigrants did go to Valdivia, although 29 of them, including women and children, all classified as farm workers, had left Valparaíso by December 1844 for North America. However, what finally became of the 674 immigrants from New Zealand and Australia is generally not known ${ }^{84}$.

In the meantime, while these events had been unfolding in the New Zealand Company settlements, northern New Zealand carried on in its usual role without experiencing the same intense interaction with Valparaíso. Occasional ships typically travelling between Sydney and Valparaíso continued to call into the Bay of Islands. The Bay of Islands also was the scene of a unique occurrence in the New Zealand-Valparaíso relationship when British naval power based in South America gave support following a request from Governor FitzRoy during the Northern War, fought between the British and Mãori in the Bay of Islands in 18451846. The HMS Daphne arrived from South America in August 1845 and remained until October that year, during which time it escorted the Slains Castle, carrying artillery and ammunition from Auckland to the Bay of Islands, and increased morale and showed the colours ${ }^{85}$. With the shift in the seat of government, the Bay of Islands lost its primacy to Auckland from 1840, where, because agriculture was

79 Joaquín Prieto, P.2432; Minna Reclan de Claude, cited in Gilberto Harris Bucher, "La inmigración extranjera en Chile a revisión; también proletarios, aventureros, desertores y deudores", Anuario de Estudios Americanos LIV-2, Sevilla, 1997, 546.

80 Valparaiso English Mercury, Valparaíso, 6 January 1844, 1 c.

81 El Mercurio [hereafter EM], Santiago, febrero 29 de 1844, 2 c.

82 Valparaiso English Mercury, 24 February 1844, 3 b, c.

83 Idem; GdelC, 26 de febrero de 1844, 3 b, c, d; $E M$, febrero 29 de 1844,2 c.

84 Miguel Bayons al intendente de Concepción, Talcahuano, 5 de diciembre de 1844, FICO, Volumen 256, Archivo Nacional de Chile, cited in Harris Bucher, "La inmigración extranjera", op. cit.; G.J. Abbott, "The Emigration to Valparaiso in 1843", Labour History 19 and 20, Canberra, 1970, $1-16$, and 1971,65 .

$85 B P P$, Correspondence and Papers Relating to Native Inhabitants, The Distribution of Land and Other Affairs in New Zealand, 5, 1846-1847, 105, 138-139; Jack Lee, "I have named it the Bay of Islands ...", Auckland, Hodder and Stoughton, 1983, 267. 
successful on its fertile soils once the scrub vegetation was cleared, the early need for Chilean flour did not arise. Some shipments of timber from Waiheke Island and Manukau Harbour were sent to Valparaíso during the early 1840s, but were fortuitous ${ }^{86}$.

By 1844 , therefore, it seemed as though the connection between the nascent New Zealand colonies and Valparaíso had quite suddenly run its course. The number of ships dropped significantly and mail continued to dramatically decline over subsequent years ${ }^{87}$. Cereals were being grown in New Zealand at an increasing rate and thus undermining the incipient New Zealand-Valparaíso trade almost as soon as it had begun. Nelson, for instance, was thought to have over 809 hectares under cultivation by 1845 of which some 243 hectares were in wheat ${ }^{88}$. At the Select Committee on New Zealand in 1844, G.B. Earp, who went to New Zealand to set up a merchant firm and to farm, stated that he hoped New Zealand would not always be importing flour, suggesting that the importation of flour and wheat from Chile was only ever seen as a temporary measure. His viewpoint may have reflected a New Zealand Company principle that gentlemen farmers should produce wheat for the British market by using immigrant British labour and New Zealand land ${ }^{89}$. Yet even before the New Zealand colonies were founded, Valparaíso's international network had in fact begun faltering, as the city entered a long period of economic malaise during Chile's war with the Peru-Bolivian Confederation ${ }^{90}$. Continued adverse factors in the region caused uncertainty and instability in the business environment and had a detrimental effect on British merchants in Valparaíso - the very persons most likely to connect Valparaíso and New Zealand then ${ }^{91}$.

\section{$1850-1896$}

During the 1850 s and early 1860 s some Chilean flour arrived in New Zealand, but it was only an accumulation of certain events that saw New Zealand become briefly dependent on imported cereals and caused merchants to turn to Chile for supplies once again. First, by the early 1860s Mãori had stopped growing wheat on account of land exhaustion and lower returns from tainted seed, while meat and dairy products gave a better return to European farmers than growing wheat.

86 Registros Navieros, Entradas, Valparaíso, 1840; EMV, 6 de julio de 1840, 3 c; GdelC, 28 de marzo de 1844, 3 d; R.G. Jameson, New Zealand, South Australia and New South Wales: A Record of Recent Travels in these Colonies, etc, London, Smith, Elder, 1842, 288; Cumberland, "Jimmy Grants" and "Mihaneres", op . cit., 72; Paul Monin, Waiheke Island: A History, Palmerston North, Dunmore Press, 1992, 66; Christopher Paxton, "Cornwallis: Graveyard of Dreams", New Zealand Memories 68, Auckland, 2007, 65 .

87 BPP, Affairs of New Zealand, Table 1, No. 41, 6, 1847-1850.

88 New-Zealander, 15 November 1845, 4a.

89 BPP, Minutes of Evidence Taken Before Select Committee on New Zealand, 2, 102; Alan Grey, Aotearoa and New Zealand: A Historical Geography, Christchurch, Canterbury University Press, 1994, 189.

90 Jacqueline Garreaud, "La formación de un Mercado de Tránsito: Valparaíso: 1817-1848", Nueva Historia 11, año 3, Londres, 1984, 179-185.

91 Rory Miller, Britain and Latin America in the Nineteenth and Twentieth Centuries, London and New York, Longman, 1993, 79-80. 
Second, there was the need to provision the armed forces while they were stationed in Auckland at the time of the Waikato Land War (1863-1864). Third, the gold rush in Otago created a demand for cereals from 1861. Fourth, the situation between 1863 and 1865 was exacerbated by dry years in California ${ }^{92}$.

Therefore during 1864 T.J. Peacock and Company of Christchurch sent a representative to Valparaíso to arrange a consignment of flour ${ }^{93}$. The shortage of grain in New Zealand and the high price it was fetching became widely known in Chile in September 1864 through a report in El Mercurio quoting Captain Watt of the Emerald. For merchants in Valparaíso -who could not sell wheat in the Australian colonies under a certain price because of the cost of freight, commission, insurance, risk of damage, warehouse costs and the price of wheat in Valparaíso- the pressure on the price of wheat and flour made it worth their while to re-enter the New Zealand market ${ }^{94}$. Between 1864 and 1870, therefore, some 78 ships left the Chilean coast from Valparaíso, Tomé, San Antonio, Constitución, Concepción, Talcahuano, Papudo, Pichidangui Bay, Quintero and "Curruimbe" (a newspaper's rendering) to bring flour and wheat to Auckland, Wellington, Nelson, Christchurch and Dunedin. Indeed, the enormous volume and frequency of flour and wheat that came from Chile was very impressive and showed that again Chile fed European New Zealand when it was most vulnerable. In short, Chilean flour and wheat were once again converted into cheaper bread ${ }^{95}$.

Other articles were imported into New Zealand from Chile also, admittedly in much smaller quantities, but possibly taking advantage of the renewed link: walnuts, straw hats, donkeys, bags of beans, biscuits, macaroni, vermicelli, scrap metal, liquour and dunnage. In return, consignments of timber were taken from Stewart Island and Kennedy's Bay on the Coromandel Peninsula. The value of imports from Chile into New Zealand in 1865 was officially the highest after Britain, New South Wales and Victoria ${ }^{96}$. June of that year also saw the appointment of James Burtt, who had lived in Chile, as Chilean consul in Auckland, and whose duties included having letters and extracts from Chilean newspapers published in New Zealand newspapers to keep the public informed ${ }^{97}$.

92 Southern Cross, Summary for May 1863, 4; Nelson Examiner, Nelson, 14 December 1866, 3 b; Grey, op. cit., 203; R.P. Hargreaves, "The Maori Agriculture of the Auckland Province in the MidNineteenth Century", Journal of the Polynesian Society 68:2, Auckland, 1959, 76; James Belich, The New Zealand Wars and the Victorian Interpretation of Racial Conflict, Auckland, Auckland University Press, 1986, 125-126; Duncan Mackay, Frontier New Zealand: The Search for Eldorado 1800-1920, Auckland, Harper Collins Publishers New Zealand, 1992, 64.

93 Keeble, op . cit., 85-86.

94 EM, 13 de septiembre de 1864, 3 b; Charles Hursthouse, New Zealand, the "Britain of the South”, London, 1861 [Facsimile edition, Kiwi Publishers, Christchurch, 1997], 188-189.

95 New Zealand Herald [hereafter $N Z H$ ], Auckland, 9 January 1865, 5 d; Nelson Examiner, 16 October 1866, 2 c. Two mills mentioned in newspapers as producing the flour that came to New Zealand were the Santiago de Collén and the Molino del Carmen, ODT, 6 February 1865, 3 c; Weekly News, Auckland, 16 September 1865, 17 a, 18 d; Nelson Examiner, 13 January 1866, 1 c.

96 [Registrar-General of Births Deaths and Marriages], Statistics for the Colony of New Zealand for the Year 1865, Total Value of Imports/Port, Number 14, By Authority, Wellington.

$97 E M$, junio 19 de 1865,3 d; NZH, 9 July 1866,3 a. 
Notably, too, the berths of returning ships were frequently full with passengers from New Zealand ${ }^{98}$. Yet, even though New Zealand and its goldfields were known both in Valparaíso from quotations in flour prices at Dunedin, Nelson and Hokitika and in Concepción, Chileans never came to New Zealand in numbers approaching those who went to the goldfields in California and Australia (Latin Americans were always a rarity in New Zealand). Those who did settle in different parts of the country may have deserted from the "flour ships" -notorious for bad disciplinesuch as Joseph Ascenco (or Assentio as shown on his Death Certificate), a bushman buried in Tairua in 1876 at the age of 40, who may have been a crewman on the Hansa which went to Kennedy's Bay in 1867 to take on board timber after it unloaded its cargo of flour in Auckland ${ }^{99}$. Certainly, entry into New Zealand for Chilean sailors was not easy as suggested in the case of the Gloriosa in 1865 , whose four deserters were pursued by the Port Chalmers water police to the upper harbour after the ship's captain reported them missing. The police caught one crew member, who was charged with desertion and sentenced to 12 weeks' imprisonment, while the other three evidently vanished into the streets of Dunedin ${ }^{100}$.

The market in Auckland became saturated in June 1865 with the huge amounts of flour and wheat the "flour ships" brought and Dunedin soon after in SeptemberOctober (for example, the 16,112 one-hundred-pound bags of flour destined for Dunedin in May 1865 on the British barque Eleanor Wood was the largest single consignment to arrive from Chile at the time) ${ }^{101}$. Even during 1864-1867, Chilean cereals in New Zealand competed against grain from South Australia, Tasmania, California, England and ultimately the South Island of New Zealand. Further, the Spanish blockade of Chilean ports in 1865-1866, and the interruption to the trade it caused, placed the reliability of Chile as a supplier in doubt in the minds of New Zealand buyers. By April 1866 the price of Chilean flour fell following a

$98 E M$, abril 5 de 1865, 3 c; Otago Daily Times [hereafter ODT], Otago, 9 May 1865, 4 a; 7 July 1865, 4 a; 6 April 1866, 4 b; 1 May 1866, 4 a; NZH, 22 January 1867, 3 a; Port Chalmers Police Diary of Duty and Occurrences, 1863-1867, 2 March 1865, 18 March 1865, 6 May 1865, AAWC D166/12, Archives New Zealand, Dunedin.

99 The information given in documents on the following Chileans suggests that they arrived during the "flour ship" period: Register of Persons Granted New Zealand Citizenship 1843-1948, Series A-G AAYQ/4a, 89 (Antonio Dennis from Valparaíso, a settler in Ashburton in Canterbury), 98 (Elias Duo from Valparaíso, a cook at Feldwick in Southland), 140 (Peter Gonzales from Chile, a labourer in Auckland), and Series H-N AAYQ/4b, 274 (John Moura from Laguna Verde, a labourer in Dunedin), Archives New Zealand, Auckland; New Zealand Archaeological Association Site Record Form T11/831; Folio Number 1876/49, Reference No. 3-0101207 (Joseph Assentio), Births Deaths and Marriages, Central Registry, Lower Hutt. On the issue of ship discipline: Auckland Court, 11 April 1865, 158, BADW 5989/22, Archives New Zealand, Auckland; Port Chalmers Police, op. cit., 23 and 24 January 1865, 1 and 2 March 1865, 8 November 1865, 27 February 1866, 26 and 27 March 1866, 24 and 25 April 1866, AAWC D166/12, Archives New Zealand, Dunedin. Also, the term "flour ships" appears in Wakefield's Adventure in New Zealand from 1839 to 1844 to describe vessels that come into Port Nicholson from Valparaíso loaded whit flour, op. cit., I:419.

100 Port Chalmers Police, op. cit., 22 and 23 January 1865, AAWC D166/12, Archives New Zealand, Dunedin

101 ODT, 31 May 1865, 4 a. 
successful wheat harvest in South Australia and some further arrivals of ships from Chile that had run the blockade. Nonetheless, behind the eventual disappearance of the "flour ships" was the re-orientation of Chilean exports of grain from the Pacific markets to European ones. Chile was in the process of economic neo-colonization forming a closer economic relationship with Britain. The export of Chilean cereals to Britain had been growing since 1860 because of different factors -such as improved sailing vessels and better geographical knowledge- and about 1865-1867 the new and important British market opened for Chilean producers. By July 1868 merchant houses in Valparaíso were holding grain orders in preference for the English market ${ }^{102}$. Following the "flour ship" years there was a lull that even gave cause for the Chilean consul in New Zealand, David Boosie Cruickshank, an Auckland merchant, to inform the Chilean Minister of Foreign Affairs in 1874 that no business worthy of communicating had occurred since he took up his appointment in 1872 . The next year he reported that no Chilean vessels had visited Auckland and that he had not had any occasion to use his consular powers ${ }^{103}$.

The British also assisted in introducing new technology to Chile and in modernizing various sectors of the Chilean economy after the War of the Pacific (1879-1883). This war gave considerable impetus to industrialization, agriculture and transport in Chile, and the republic emerged from its conflict with Bolivia and Peru with transformed prospects. The Chilean economy was sustained in the $1880 \mathrm{~s}$ by the strong growth of the new nitrate industry at Tarapacá and Antofagasta, secured from Peru and Bolivia respectively ${ }^{104}$. The British soon came to dominate the Chilean nitrate industry and link it to the world economy ${ }^{105}$. While they were the most skilled and professionalized national group in Chile, there were never many of them. In fact, in spite of substantial British and other foreign investment, there was little European migrant flow to Chile: by 1885 the British population was just over 5,000 , living mainly in Valparaíso and the provinces generating exports ${ }^{106}$.

As the nitrate industry expanded, the New Zealand-Valparaíso business connection revived. However, this time it was New Zealand business that made the leap and established itself in Chile, although never far from British business interests. In the frontier and colonization settings, the New Zealand-Latin

102 Sepúlveda, op. cit., 61; "Valparaiso and West Coast Mail of $3^{\text {rd }}$ June 1868", cited in $O D T, 28$ July 1868,4 b.

103 D.B. Cruickshank to the Minister of Foreign Affairs, Santiago de Chile, 18 April 1874, Cónsules de Chile en América y Europa, Australia, Nueva Zelandia, Hawaii, Volumen 50, Letra C, Ministerio de Relaciones Exteriores, Archivo General Histórico, Santiago; Cruickshank to the Minister of Foreign Affairs, Santiago de Chile, 25 October 1875, oficios recibidos de los Cónsules de Chile en América, Europa y Australia, Volumen 52, Letra C, Ministerio de Relaciones Exteriores, Archivo General Histórico, Santiago.

104 Harold Blakemore, "From the War of the Pacific to 1930", in Leslie Bethell (ed.), Chile Since Independence, Cambridge (England) and New York, Cambridge University Press, 1993, 34-36; Roberto Cortés Conde, The First Stages of Modernization in Spanish America, New York, Harper and Row, 1974, 66-67.

105 Miller, op. cit., 170; John Mayo, "Britain and Chile, 1851-1886: Anatomy of a Relationship", Journal of Interamerican Studies and World Affairs 23:1, Miami, 1981, 115-116.

106 P.J. Cain and Anthony G. Hopkins, British Imperialism: Innovation and Expansion 16881914, London and New York, Longman, 1993, 231. 
American relationship was characterized by intermittent shipping, merchant networks and some exploitative and trading connections with Valparaíso. By the early 1880s, as New Zealand historian James Belich argues, New Zealand's relationship with Britain was being renewed in a process of recolonization, affecting New Zealand politically, economically, socially and culturally. For the New Zealand-Latin American relationship New Zealand recolonization meant a steadier connection based on a British presence, investment capital, trade, knowhow and migration ${ }^{107}$. Hence Thomas Dawson was appointed the South British Fire and Marine Insurance Company's agent in Valparaíso in 1883. At first he had difficulties in establishing business relations in Chile because the New Zealand company was a colonial one and was not yet known in South America. Even so, business in Chile yielded the bulk of the company's income in Latin America, with much of the business coming from marine insurance on nitrate ships, the coastal trade and fire insurance. Also present in Valparaíso about this time were the Bank of New Zealand, represented by the Banco Nacional de Chile, the New Zealand Insurance Company whose agent was Armstrong and Company, and the Colonial Bank of New Zealand, represented by the Banco de Valparaíso ${ }^{108}$. Josiah Harding -notable for railway, engineering and architectural works in Chile and Boliviawrote to his father in New Zealand from Antofagasta in 1887 that there were moves afoot to form a company to import frozen meat and other provisions from New Zealand to supply the large local mining population and navvies constructing a railway ${ }^{109}$. In the following year the first export of New Zealand fruit to South America was sent to Chile from Christchurch ${ }^{110}$. Then the Dunedin-based Westport Coal Company set out to supply coal for shipping in Valparaíso. After much difficulty in finding a vessel to go to Westport, the company successfully chartered the Cynosure to take a shipment of the company's coal to Valparaíso in 1896. The coal was well received and orders for further shipments were placed, but this was to be the first and last consignment because the company had problems with shipping, the prospect of high freight charges and its own inability to supply the coal $^{111}$. Nonetheless, it was proven that New Zealand ventures could be successful in Chile. Now New Zealand was looking outwards and a similar outward drive took place in Platine Argentina.

107 James Belich, Paradise Reforged: a history of the New Zealanders from the 1880s to the year 2000, Auckland, Allen Lane and Penguin Press, 2001, 29; James Belich, Peplenishing the Earth: The Settler Revolution and the Rise of the Anglo-World, 1783-1939, Oxford, Oxford University Press, 2009, 177-180.

108 C.W. Vennell, Risks and Rewards: a policy of enterprise 1872-1972: a centennial history of the South British Insurance Company Limited, Auckland, Wilson and Horton for South British Insurance, 1972, 197-198; Australasian Insurance and Banking Record 14, Melbourne, 1890, advertisements, $v$.

109 "Josiah Harding", in Virgilio Figueroa (ed.), Diccionario Histórico, Biográfico y Bibliográfico de Chile, Volumen 3, Santiago de Chile, 1929, 427; New Zealand Farmer [hereafter $N Z F]$, Auckland, May 1887, 152 d.

110 Rex Monigatti, Fruitful Years, Wellington, New Zealand Fruitgrowers' Federation Limited, 1966,66 .

111 Fifteenth Annual Report of the Westport Coal Company Ltd., February 1897, Dunedin, Hocken Library, 6; Westport Coal Company Annual Report, February 1900, Dunedin, Hocken Library, 5. 


\section{Platine Argentina}

1869-1890

Given the centrality of the Pacific in this article so far, New Zealand's presence in Platine Argentina may seem paradoxical since New Zealand was "at the outermost location on any Atlantic-based schema"112. Several early contacts with Platine Argentina are known: Tippahee Cupa, a Mãori chief from Cook Strait, while accompanying Captain Reynolds, "a South Sea trader", on the Urania to London, was hospitably entertained in 1824 by English residents in Buenos Aires, and then in 1833 the brig Spy from Buenos Aires was recorded by a contemporary as being in New Zealand waters trading shells ${ }^{113}$. By 1869 , when J.D. Tetley, a run holder "on a large scale" of Kekerenga and Starborough stations in Marlborough and member of the Legislative Council, decided to go to Argentina after getting into financial difficulties, a drift from New Zealand to the Río de la Plata by run holders and "the younger sons of New Zealand sheep farmers" may have been under way ${ }^{114}$. Links may have existed between estates in New Zealand and the estancias (ranches) of Platine Argentina, where British had been raising stock since the $1820 \mathrm{~s}^{115}$. Then, during the $1880 \mathrm{~s}$ the pace of migration picked up when Argentina became a destination for New Zealanders.

One effect of the Long Depression in New Zealand (1879-1896) was net emigration. While marking a "great slow-down" in the New Zealand economy, the wider implication of the depression was a transitional period from an extractive economy based on timber, gold and kauri gum to a sustainable national one that produced meat and dairy products ${ }^{116}$. Argentina underwent a similar profound national political and economic transformation during the $1880 \mathrm{~s}$. The defeat of the pampean Indians in the early 1880 s in the "conquest of the wilderness" doubled the size of the Province of Buenos Aires and added extensive areas to the national public domain south of the Río Negro. And after some seventy years of political instability, the Partido Autonomista Nacional came to power committed to

112 Donald Denoon, Settler Capitalism, Oxford [England] and New York, Clarendon Press and Oxford University Press, 1983, 111.

113 Robert McNab (ed.), Historical Records of New Zealand, Wellington, Government Printer, 1908, 635-640; George Lillie Craik, The New Zealanders, London, Knight, 1830, 320; Michael G. Mulhall, The English in South America, Buenos Aires, Standard Office, 1878, 607; 25 March 1833, Ransome Journal, NPL:MS A1481, Mitchell Library, State Library of New South Wales, Sydney.

114 [The Cyclopedia of New Zealand Company], "Past and Present Members of Parliament", The Cyclopedia of New Zealand. Volume 5. Nelson, Marlborough and Westland, Christchurch, The Cyclopedia Company, 1906, 310; Cross (ed.), op. cit., 14; Herbert Gibson, The History and Present State of the Sheep-Breeding Industry in the Argentine Republic, Buenos Aires, Ravenscroft and Mills [Facsimile edition, Bibliobazaar], 1893, 215; Weekly Press, Christchurch, 15 September 1897, 17 c; The Times, 28 April 1905, 8 f and 5 May 1905, 3 d; Edelmiro A. Correa Falcón and Luis Klappenbach, La Patagonia Argentina, Buenos Aires, G. Kraft, 1924, 132.

115 Roy Hora, "Britain, the British Landed Class, and Argentine Landowners", Canadian Journal of Latin American and Caribbean Studies, January 2005, online, available at: http://findarticles.com, 3.

116 Belich, Paradise Reforged, op. cit., 32-38; Tom Brooking, The History of New Zealand, Westport (Connecticut), Greenwood Press, 2004, 74. 
enforcing the state's authority and promoting trade, investment, infrastructural development and immigration ${ }^{117}$. After then, Argentina constructed its national prosperity around the export of pastoral and agricultural products - Britain provided much of the investment capital, directed at railways, docks, public utilities and works, national and municipal loans, agriculture and frigorificos (the equivalent to the freezing works in New Zealand). In the pastoralist sector in particular, modern technologies, such as fences, and more elaborate buildings and housing, became common on estancias. Pedigree breeders and studs became widespread, and the Sociedad Rural Argentina began to keep pedigree animal registers. Purebred livestock were imported mainly from Britain instead of continental Europe as before, and merinos were replaced by Lincoln sheep which provided more suitable meat for freezing for the new frigorificos. The Argentinian government also sent a number of fact-finding missions overseas, including Ricardo Newton of the Estancia Los Jagueles who was commissioned by the government to study the wool industry and spent nearly a year in New South Wales, Victoria and New Zealand in $1883^{118}$.

Furthermore, Argentina was to the forefront in the development of the frozen meat export trade. The shift from preserved meat produced by the saladeros (meatsalting plants) to frozen meat had been made possible by the work of Charles Tellier, who communicated his first successes to the Academy of Sciences in Paris in 1872. Five years later, the Paraguay took frozen meat from Buenos Aires to Marseilles without, for the first time, any spoilage to the meat. At the instigation of Queensland squatters who had heard of the voyage of the Paraguay, the Strathleven successfully carried frozen meat on the longer and more costly route from Australia to England in 1880-1881. Aware of the success of the Strathleven, Thomas Brydone and William Soltau Davidson of the New Zealand and Australia Land Company organized a cargo of frozen company lamb and mutton from Oamaru in the South Island to England on the Dunedin in 1882. John Grigg, owner of Longbeach station in Canterbury, who knew of Argentina's shipment of frozen mutton in 1877 , also sent some frozen lamb on the Dunedin ${ }^{119}$. In view of the improvements in the livestock industry and the development of the Argentinian frozen meat export trade, it is understandable that Walter Tylee, a farmer from

117 Félix Luna, Breve Historia de los Argentinos, Buenos Aires, Planeta, 1993, 121-122; James R. Scobie, Revolution on the Pampas: a social history of Argentine wheat, Austin (Texas), published for the Institute of Latin American Studies by the University of Texas Press, 1964, 15-18; Jonathan C. Brown, A Brief History of Argentina, New York, Facts on File, 2003, 142; David Rock, Argentina 1516-1987, Berkeley, University of California, 1987, 154-155; Hora, op . cit., 8.

118 Gibson, op. cit., 198; Tim Duncan and John Fogarty, Australia and Argentina on Parallel Paths, Carlton [Victoria], Melbourne University Press, 1986, 1.

119 James T. Critchell and Joseph Raymond, A History of the Frozen Meat Trade, London, Constable, 1912, 28, 39-43; Scobie, op . cit., 116; Kenneth Cumberland, Landmarks, Sydney, Reader's Digest, 1981, 122; Belich, Paradise Reforged, op. cit., 56, 61; José Gabriel Vazeilles, Historia Argentina: Etapas Económicas y Políticas 1850-1983, Buenos Aires, Editorial Biblos, 1997, 56, 217. William Soltau Davidson had been planning to go to Argentina where a relative had an estancia before deciding on New Zealand, A Lasting Legacy: A 125-year history of New Zealand farming since the first frozen meat shipment, Auckland, New Zealand Rural Press, 2007, 20. 
Makuri in the North Island, stayed at the "River Plate" in 1887 to broaden his knowledge of the pastoral industry before returning to New Zealand ${ }^{120}$.

In later years, Ewart Grogan writing from the Savage Club in London stated that during the reconstruction of the Argentinian pastoral industry by British pastoralists from the 1880 s, New Zealanders in Argentina had perhaps played the most important part ${ }^{121}$. When Captain Baldwin, an Otago run holder, travelled the Province of Buenos Aires about 1885, he found New Zealand connections throughout the province. He visited Estancia Negretti, situated about 130 kilometres by rail from Buenos Aires and regarded as the model estancia in the Province of Buenos Aires. It was owned by David Anderson Shennan, brother of Watson Shennan of Conical Hills station near Tapanui in Otago. David Shennan had gone to Otago in 1864, but returned to Scotland. He then went to Argentina where he managed a property adjoining the Estancia Negretti for a British company. He had been successful, and in partnership acquired the Estancia Negretti in 1870. He employed George Evans, a one-time Otago run holder, as his manager. Also, the estancia was the site of Argentina's first sheep dip and -with Shennan well known for hospitality- the first polo match played in South America in $1875^{122}$. The Estancia Espartillar was a further 19 kilometres on, owned by John Fair, an Anglo-Argentinian. The estancia, with its origins in the first days of the sheep-breeding industry in the Plata, was managed by Frank Tetley, New Zealandborn son of J.D. Tetley ${ }^{123}$. In the vicinity of Bahía Blanca, the vast Curumalán Estate of Edward Casey was managed by a nephew of the Honourable Colonel Brett of Canterbury, and another estancia nearer Bahía Blanca, owned by an Englishman, employed a son of Dr Issac Featherston (former politician and AgentGeneral for the Colony of New Zealand in London).

From 1884 the New Zealand Shipping Company and Shaw Savill and Albion Company introduced a steamship service between New Zealand and Britain via Rio de Janeiro as a port of call ${ }^{124}$. Easier access to Argentina opened it to New Zealanders, and by the mid 1880s a community of New Zealanders lived in Argentina: John Maitland Paxton later remembered "young Hayward of Tomlinson and Hayward, the sheep dip people", as well as W.E. Leach of Cust, Mr Hood of Waikari, a son of Mr Helmore (a landowner in the Ashburton district and member of the local gentry), and Mrs Shannon of Otago and her daughter. George O'Connell, too, met in later years on his way to being manager of an estancia in Santa Fe, had left Canterbury in 1887 for Argentina. Among the earliest Plata frigorificos established, John Ward, who had been in the New Zealand frozen meat

120 [The Cyclopedia of New Zealand Company], "Makuri", The Cyclopedia of New Zealand. Volume 1. Wellington Provincial District, Wellington, The Cyclopedia Company, 1897, 1058.

121 The Times, 28 April 1905, 8 f, 5 May 1905, 3 d.

122 Press, Christchurch, 2 December 1885, 5 g; Gibson, op. cit., 209-215; Mulhall, op. cit., 409; Jack Shennan, "Shennan-Macdonell: A Short Family History", Alexandra Museum, typescript, 1972, 4-5.

123 Press, 2 December 1885, 5 g; Gibson, op. cit., 215-219.

124 Sydney Waters, Clipper Ships to Motor Liner, London, New Zealand Shipping Company, 1939, 32; Waters, Shaw Savill Line: One Hundred Years of Trading, Christchurch, Whitcombe and Tombs, 1961, 74 . 
business since 1884, worked for the Compañía Sansinena de Carnes Congeladas in 1887 as its "general Europe manager"125. Noteworthy was John Leesmith's appointment as Argentinian consul in Dunedin in 1888 when there was no trade between New Zealand and Argentina to otherwise justify it ${ }^{126}$.

Influential people in New Zealand who visited Argentina -Captain Baldwin (also one-time Commissioner of the Waitahuna Goldfield in Otago), Sir John Hall (New Zealand Premier between 1879 and 1882) and Paxton (a Christchurch grain merchant)- gave favourable reports on the pampas in newspaper interviews after returning to New Zealand (despite certain drawbacks such as language and the prevalence of scab and foot-rot) ${ }^{127}$. They were backed up by items in local newspapers that appeared from time to time on the remarkable progress and resources of Argentina. And the various reports found an audience in New Zealand: in November 1886 Sir John Hall received a letter from G. Spence, a sheep farmer for 23 years in Hawke's Bay, who had read about Argentina in a newspaper and the comment that Hall's son was there, and sought information on Argentina "where things may be better"128.

George Ogilvie, chairman of the Santa Fe Company, explained that

"during the years $1885,1886,1887$ and 1888 , there was a great boom in land. Foreigners were pouring in, bringing capital; great confidence was put by foreign capitalists in the country, several railways had run out new branches, new railways were built, new banks were opened, and a very large extent of land was opened up and cultivated, and put under wheat and linseed, harvests were good and money was flowing into the country" 129 .

Amid these boom conditions, several New Zealand companies were also drawn to Argentina. A branch of the New Zealand Insurance Company was opened in Buenos Aires in $1886^{130}$. The South British Insurance Company appointed an agent to Buenos Aires in 1887 to write fire business ${ }^{131}$. And the Auckland -and Londonbased New Zealand Land Mortgage Company, in reaction to low interest on money loaned on mortgages in New Zealand, became known as the New Zealand and River Plate Land Mortgage Company Limited in 1889 with shareholders' approval

125 Press, 9 August 1886, 3 b; Weekly Press, 15 September 1897, 17 g; Critchell and Raymond, op. cit., 82; Stevan Eldred-Grigg, "Whatever Happened to the Gentry? The Large Landowners of Ashburton County, 1890-1896", New Zealand Journal of History 11:1, Auckland, 1977, 21.

126 Despatches No. 27, No. 54, No. 82, Appendices to the Journals of the House of Representatives, 1889, A.-1, 30-31.

127 New Zealand Electoral Rolls, Christchurch North, 1885-1886, 24; Press, 10 October 1885, 3 b; 2 December 1885, 5 g; 9 August 1886, 3 a; NZF, January 1886, 20 a, b; $O W$, 1 July 1887, 9 c, d; Robert Gilkison, Early Days in Central Otago, Christchurch, Whitcombe and Tombs Limited, 1961 reprint, 25.

128 Spence to Hall, 1886, Sir John Hall Papers, Series 1, MS-Papers-1784-131, Alexander Turnbull Library, Wellington.

129 Campbell Patrick Ogilvie, Argentina from a British Point of View and Notes on Argentine Life, London, Wertheimer, Lea, 1910, 47.

130 [New Zealand Insurance Company], Bold Century: The New Zealand Insurance Company Ltd., 1859-1959, Auckland, Wilson and Horton, 1959, 27, 29.

131 Vennell, op. cit., 119. 
and began business in Buenos Aires. Soon afterwards, the company disposed of its New Zealand business and centred its operation wholly in Argentina ${ }^{132}$. By 1890 , too, the London and River Plate Bank acted as agent for the Colonial Bank of New Zealand and the Bank of New Zealand in Argentina ${ }^{133}$.

\section{3-1914}

In 1890, following financial collapse and political upheaval, the Argentinian economy went into depression, and the country went on to experience "several more lean and gruelling years"134. During the first half of the decade news about Argentina was not good in New Zealand with reports of a breakdown in law and order, a worthless paper currency, reduced returns for the railways and so forth, and New Zealanders were urged then not to seek their fortune in Argentina ${ }^{135}$. As the Argentinian economy recovered from 1895-1896, however, New Zealanders once again made Argentina a destination. It is not known how many New Zealanders emigrated to Argentina, but Captain Albert William Pearse, editor of The Pastoralists' Review published in Melbourne, asserted in 1901 that "not a few New Zealanders" had found their way to estancias in Argentina. In 1904 the special London correspondent for the New Zealand Mail wrote "a good number of New Zealanders were scattered about the 'estancias' of the River Plate country". And, as alluded to, Ewart Grogan and William Pember Reeves, Agent-General in London, exchanged letters in 1905 in the columns of The Times for several weeks debating "the flow of New Zealand farmers" to Argentina. Reeves put the figure at 100 , and argued they had gone before 1890 because "for the last fifteen years New Zealand has lost no population at all to South America" (he later conceded that "an occasional individual" had gone to Argentina) ${ }^{136}$. Yet, at a time when most British migrants tended to go to the British colonies and dominions, the promise of opportunities in pastoralism continued to draw New Zealanders to Argentina. A few weeks after the public debate between Grogan and Reeves had died down, the New Zealand Herald correspondent in London had a visit from "a gentleman who holds a recognized position in New Zealand, and who is now on a visit to the Mother Country" who claimed that there had been an "exodus" from New Zealand to Argentina as Grogan had maintained ${ }^{137}$.

132 NZH, 23 August 1888, 5 c; 17 January 1889, 5 g; 26 February 1889, 6 a; 13 March 1889, 6 d; Australasian Insurance and Banking Record 13:2, Melbourne, 16 February 1889, 101; Press, 17 September 1890, 6 d; J. Fred Rippy, British Investments in Latin America, 1822-1949, New York, Arno Press, 1977, 166; Russell Stone, Makers of Fortune, Auckland, Auckland University Press, 1973, 74,184 .

133 Australasian Insurance and Banking Record 14, Melbourne, 1890, advertisements, v.

134 Rock, "The Argentine Economy, 1890-1914: Some Salient Features", in Guido di Tella and D.C.M. Platt (eds.), The Political Economy of Argentina, 1880-1946, Basingstoke, Macmillan in association with St Antony's College, 1986, 60-62.

135 Press, 10 January 1893, 4 d.

136 New Zealand Mail, Wellington, 16 October 1901, 31 d, 20 July 1904, 66 c; The Times, 25 April 1905, 2 e; 27 April 1905, 3 f; 28 April 1905, 8 f; 2 May 1905, 1 b; 5 May 1905, 3 d, e; 11 May 1905, 4 d; 16 May 1905, 10 c.

$137 \mathrm{NZH}, 26$ July 1905,3 e. 
This later "second wave" of New Zealand migrants included settlers, such as Henry Gray of Blackford station in Canterbury who, doubting the Liberal government's attitude to New Zealand landowners, purchased an estancia about 1899 and had his son Wyndham manage it; Joseph Haydon kept ownership of his sheep farm at Hawarden in Canterbury after having purchased the Estancia La Virginia Isla Verde in the Province of Córdoba and lived as a rentier in Buenos Aires during the 1900s while his son George managed the estancia; Edward Acton, whose father was a sheep farmer at Mount Pleasant, was a farmer at Alberdi in the Province of Buenos Aires; George Richardson, a farmer at Raes Junction in Otago, was already an estanciero (rancher) when his brother, James, a gardener at Roxburgh, went with his wife to take up a farm in 1910 inherited from an uncle, James Temple, at the small settlement of James Temple in the Province of Córdoba; Vernon Musgrave sold the Upper Lake Heron station about 1898 and went to Argentina; Henry Hill, of Avonside, acquired the Estancia Carbó in Entre Ríos after the South African War (1899-1902); and John Teschemaker farmed in the Province of Santa Fe. There was also Richard Wilson, a law clerk in Dunedin, who left to become a stockman at San Jorge El Día in the Province of Buenos Aires; Arthur Campbell, of Yaldhurst, a manager of an estancia; J.L. Graham, of Temuka, managed one of the Gibson Brothers' Pampa Central estancias consisting of some 36,000 hectares; Mr Stent from Wanganui; and from the Wanganui Collegiate School Denis Gorton, Edward Gorton, William Birch, Ernest Haydon, Harold Fitzherbert and Frederick Jenkins, all went to farm in Argentina before the First World War ${ }^{138}$.

The self-confidence of the New Zealanders and their ability to assimilate came from their association with British people around them, as revealed by an Old Boy of Christ's College in Christchurch in a newspaper article: he was an assistant on an estancia in the Province of Santa Fe about 1911. He worked with up to ten Argentinian-born, Italian and Spanish peones (labourers), whom he did not find to be "very intelligent workmen and are rather difficult to teach anything new". His social outlet, therefore, was in the nearby town of Venado Tuerto. The town was in a "very English district" where "we have more than the usual number of accessible

138 EP, 25 October 1906, 7 i; $O W, 23$ May 1906, 7 b; Haydon George Reginald, Probate, Series CH 5451/1905, and Haydon Joseph, Probate, Series CH 6688/1909, Department of Justice, High Court, Christchurch, Archives New Zealand, Christchurch; Haydon Joseph, R353 and R354, G.R. Macdonald, Dictionary of Canterbury Biographies, Canterbury Museum, Christchurch; Acton Edward Ottery, Probate, Series TU 700/1904 Department of Justice, District and High Court, Timaru, Archives New Zealand, Christchurch; R.B.B. Wilson, Probate, Pr 639 1909, Series DAAC 9075/307, Archives New Zealand, Dunedin; J. Richardson, Probate, Pr 994/58, Series DAAC 9076/657, Archives New Zealand, Dunedin; The School List of Christ's College Grammar School from 1850 to 1921, 4 edition, Christchurch, published under the auspices of the Christ's College Old Boys' Association (Inc.), 1921, 140; The Nelson College Old Boys' Register, 1856-1908, $2^{\text {nd }}$ edition, Nelson, compiled and edited by J. Harold Moore and C.H. Broad, issued by the Nelson College Old Boys' Association, 1909, 141; Wanganui Collegiate School Register. From 1854 to 1939, $2^{\text {nd }}$ edition, Dunedin and Wellington, published under the auspices of the WCS Old Boys' Association (Inc.), 1939, 71, 89, 103, 125, 138; L.G.D. Acland, The Early Canterbury Runs, and Glossary of Station Words, $3^{\text {rd }}$ edition, Christchurch, Whitcombe and Tombs, 1951, 309, 322; Gustavo Richardson, to the writer, 2005. 
people to visit". There was an English Polo and Athletic Club that was successfully organized with regular meetings. Then each year the town was crowded with English people at the annual gymkhana and a three-day race meeting, when English was spoken everywhere ${ }^{139}$.

A common bond in this "Anglo-world" on the pampas was a shared world view that derived from the mythology of Anglo-Saxonism ${ }^{140}$. The racial form of AngloSaxonism, absorbing the nineteenth-century Zeitgeist of constant human progress, postulated a "scale of civilization" in which the Victorians thought the Americans were nearest to the British and British settlers at the top of the ladder of progress, followed by other European nations, and much lower down the Asian and African peoples ${ }^{141}$. Incursions into large areas of the world were fuelled by nineteenthcentury Anglo-Saxonism, "the concept of a distinct, superior Anglo-Saxon race, with innate endowments enabling it to achieve a perfection of governmental institutions and world dominance" 142 . And one precept of the ideology was AngloSaxon superiority to less "progressive" Europeans ${ }^{143}$. This British attitude was also strengthened by reactions to shocks such as the Indian Mutiny (1857-1858), a rebellion by the African population in Jamaica (1865) and the New Zealand Wars, as well as a new outlook which emerged from a "new imperialism" at the end of the nineteenth century ${ }^{144}$.

New Zealanders also came as engineers, mining engineers, managerial staff in frigoríficos, as a surveyor and in one case a book-keeper - occupations which may have reflected the preference that London directors had for English technical, managerial and supervisory staff and sometimes skilled workers over Latin Americans in most railways, utilities and mining companies. Others came as an inventor, jockey, evangelical missionaries, an agent in the "fruit business", as New Zealand Insurance Company staff, and -in the case of a duped Wellington womana prostitute in Buenos Aires ${ }^{145}$.

\footnotetext{
139 Press, 17 May 1911, 3 c.

140 Belich, Replenishing the Earth, op. cit., 5.

141 Ronald Hyam, Britain's Imperial Century, 1815-1914: a study of empire and expansion, Lanham, Barnes and Noble, 1993, 93-94.

142 Reginald Horsman, Race and Manifest Destiny: the origins of American racial anglosaxonism, Cambridge (Massachusetts), Harvard University Press, 1981, 62-63.

143 Edward P. Kohn, This Kindred People: Canadian-American Relations and the Anglo-Saxon Idea, 1895-1903, Montreal, McGill-Queens University Press, 2004, 4.

144 Hyam, op. cit., 276, 279,

145 The New Zealand Mines Record [hereafter TNZMR], Wellington 8, 8, 16 March 1905, 347; NZF, September 1905, 774 a, b; Press, 10 July 1913, 9 d; Critchell and Raymond, op. cit., 82; F.W. Furkert, Early New Zealand Engineers, Wellington, Reed, 1953, 100; F.G. Hall-Jones, Invercargill Pioneers, Invercargill, Southland Historical Committee, 1946, 116; A.G. Compton, Pioneering on the Rivers, Wellington, Wentforth, 1948, 43-47; Margarita Allan Hudspith, Ripening Fruit, a History of the Bolivian Indian Mission, Harrington Park (New Jersey), The Harrington Press, 1958, 22-23; Les Marsh, In His Name: A Record of Assembly Missionary Outreach from New Zealand, Palmerston North, Gospel Publishing House Society, 1974, 20-28; Otago Boys' High School Old Boys' Register, containing occupations and addresses of all pupils of school from 1863 to 1938 inclusive, Dunedin, compiled and edited by F.H. Campbell, W.F. Watters, James Allan and A.J. Gillman, published by the Otago High School Old Boys' Society (Inc.), 1953, 35, 38; The School List of Christ's College, op. cit., 165, 170; Wanganui Collegiate School Register, op. cit., 58; Dominion, Wellington, 5 July 1911, 9 b; Tacon, op . cit., 9; Miller, op . cit., 140.
} 
More notable among the immigrants was Henry Reynolds, founder of the Anchor butter brand and a pioneer of the Waikato-Bay of Plenty-Taranaki butter industry during the 1880s and 1890s. He became interested in Argentina when he was in London and saw the high quality of Argentinian-produced butter, which Argentina had begun to export to Britain in 1895. In London, he made a partnership deal with British investors in Argentina, Lovell and Christmas, through which he was to take charge of a new and modern but struggling butter factory operation they had financed in Tandil in the south of the Province of Buenos Aires. Reynolds left for Argentina about 1898 without knowing either Spanish or the country, but adapted by recruiting Carlos María Rivero Haedo from Runciman and Company as an assistant, and by giving him the task of setting up dairy farms and educating farmers on the unfamiliar cream separator. In 1901 Reynolds, in association with Lovell and Christmas and Runciman and Company, launched The River Plate Dairy Company, which quickly went on to become an important and progressive company in Argentina. By 1906 the company equalled La Unión Argentina Limitada in scale of dairy production and had a central factory called Progreso, established in Buenos Aires, and strategically distributed creameries. The River Plate Dairy Company subsequently opened factories in Santa Fe at Rosario and Rafaela and in Entre Ríos at Basavilbaso ${ }^{146}$.

Nonetheless, the basis of New Zealand emigration to Argentina was pastoralist. Where once Argentinian advances in refrigeration were watched from New Zealand, New Zealanders in Platine Argentina introduced a more scientific approach to land, soils and land use that once would have been of lesser concern to landowners, but was viewed differently with the growth in rural business. New Zealanders made the land more productive and more fertile for a longer period. In sheep raising they increased sheep numbers, docked tails, cured rampant foot-rot and other diseases which before had gone untreated ${ }^{147}$. The New Zealanders' approach had evolved out of a political belief in New Zealand that if the colony was to compete with agricultural producers, its agriculture had to be run on as modern and scientific lines as possible. Furthermore, the decision of John McKenzie, as the Minister of Lands in the Liberal Government, to establish the Department of Agriculture in 1892 to give both quality control and advice had been critical in achieving this result. Overseas experts and a rigorous system of branding, for instance, ensured that butter and meat reached the British market in reasonable condition. And by 1900 New Zealand had won the reputation for producing frozen lamb and butter of good quality and value ${ }^{148}$. In 1907, therefore,

146 [La Industria Lechera], "Homenaje a D. Carlos M. Rivero Haedo", 279, octubre de 1942, Buenos Aires, 9, 11; Haralt Mortstetun, "Desarrollo de la Industria Lechera Argentina", Industria Lechera, date unknown, 30-32; Henry B. Morton, Recollections of Early New Zealand, Auckland, Whitcombe and Tombs, 1925, 150; "Notes on Henry Reynolds, 1849-1925, Pioneer of the New Zealand and Argentine Dairy Processing Industries", compiled by Bryan Reynolds, Elsie Krasting de Rivero Haedo and Carl Worker, Buenos Aires, typescript, 2004.

147 Hora, op. cit., 9; William H. Koebel, Modern Argentina: The El Dorado of To-day, with notes on Uruguay and Chile, London, F. Griffiths, 1907, 166-168.

148 Brooking, The History of New Zealand, op. cit., 81. 
William Koebel wrote that "from a scientific point of view, Argentina [...] has been years and periods of years behind New Zealand"149.

New Zealand began to export sheep to Argentina as leading estancieros replaced merinos with British meat- and wool-producing breeds and as Argentinian pedigree breeding practices developed further ${ }^{150}$. New Zealand's own sheep breeding originated from when merino sheep, imported from Australia and successful on indigenous grasses, had been found unsuited to the newly-made English pastures in wetter areas, and by the mid 1860s coarser-woolled English sheep breeds had been imported to use the new pasture. While in some cases pedigreed stud flocks or high-grade animals were kept, crossbreeding of otherwise ordinary sheep was carried out to adapt sheep to local conditions, such as James Little's development of the Corriedale breed from 1868 in North Otago ${ }^{151}$. New Zealand sheep were tried out on the Buenos Aires market as early as 1887, but it was not until 1894 that the first of regular consignments of Lincoln sheep went to Argentina from New Zealand, possibly sent from Moeraki and Hakataramea in North Otago by the New Zealand and Australian Land Company, consignor of sheep to Gibson Brothers in Buenos Aires from the mid $1890 \mathrm{~s}^{152}$. Still, the smaller, better woolled, strong-framed New Zealand Lincoln had trouble competing against the fashionable bigger, long-legged, often coarser-woolled English-bred Lincoln in the yards of Buenos Aires during the $1890 \mathrm{~s}^{153}$. Nonetheless, Argentinian breeders eventually recognized the New Zealand Lincoln as being proportioned and as another step in the evolution of the Lincoln breed ${ }^{154}$. New Zealand sheep generally enjoyed a good reputation in Argentina. Maurice Garrett, estanciero of the Estancia Cacharí and owner of a purebred flock raised from imported New Zealand sheep which had impressed him "by their uniform frames and splendid fleeces", found that "sheep imported from New Zealand are superior for their long service and retention of quality and weight of fleece". Argentinian breeders saw New Zealand as an alternative source to Britain for maintaining quality and vigour of their flocks, and there was confidence in the future of the trade in New Zealand ${ }^{155}$.

Paradoxically, while New Zealand sheep were being exported to improve the quality of sheep in Argentina, meat industry leaders and others expressed much concern in New Zealand between the 1890s and the early 1910s over competition from Argentina in meat exports and the high standard of its marketing on the British markets. Its sheer land size, the extraordinary fertility of the pampas, the huge scale of the export sector, and its closeness to markets in Europe were seen as distinct advantages that Argentina possessed ${ }^{156}$. However, in the end, New Zealand

\footnotetext{
149 Koebel, op. cit.

150 Walker Stegman, Ganados argentinos: El Campo y el Sport, cited in Hora, op. cit.

151 Grey, op. cit., 276-277; Belich, Paradise Reforged, op. cit., 62.

152 Press, 7 February 1888, 5 b; Pablo Link, La Oveja y la Lana Lincoln, Buenos Aires, Ediciones Link, 1942, 35; Gordon Parry, Hakataramea Hundred 1868-1968, Edinburgh, New Zealand and Australian Land Company Limited, 1968, 29.

$153 N Z F$, December 1899, 447 d and 448 a, b; September 1900, 358 a, b, c.

154 Link, op. cit., 27, 35.

155 Press, 20 May 1909, 2 c; Dominion, 25 August 1913, 10 b.

156 NZM, 16 October 1901, $31 \mathrm{~d}$.
} 
maintained the lead in frozen lamb and mutton despite a steady increase in Argentinian production during that period. Reasons may be put down to New Zealand's mild climate and pastures, farming practices that produced high-grade products, quality control procedures carried out during processing, and small holdings that were situated nearby and linked to freezing works, while one analysis suggests that Argentinian expansion in mutton was checked by the competing claims of wool production within Argentina and the spread of agricultural land at the expense of sheep grazing, as much as by any superiority in quality and value for Australasian and home-grown mutton on the English market ${ }^{157}$.

One breeder at the centre of the New Zealand pedigree sheep trade to Argentina was Ernest Short, the consummate New Zealand sheep breeder among his peers. Short was born at Karori in Wellington in 1871, and went to the Feilding district while young. After finishing schooling at Makino, he went to work on a farm in the Waituna area. By then, the Romney Marsh breed of sheep had been introduced on the extensive Manchester Block (in Manawatũ), and Short saw the breed was particularly suited for the district. He began to study the Romney Marsh, and followed the judges at the Agricultural and Pastoral Shows observing the methods by which the breed was judged. He also acquired land, especially at Waituna, where his Parorangi property became famous for its Romney Marsh sheep and Hereford cattle. Indeed, he was recognized throughout New Zealand as one of the leading breeders, and during the time he was exhibiting at the principal Agricultural and Pastoral Shows, he was an unbeaten champion. He experimented in developing breeds of sheep, cattle and horses, and paid big prices for the best stud Romney Marsh and Herefords in England to improve his flocks and herds. Then, in 1907, he began to export Romney Marsh sheep to South America ${ }^{158}$. A high-point in Short's career was his participation at the Grand International Agricultural Exposition held in the grounds of the Sociedad Rural at Palermo in Buenos Aires in 1910, which he said would give "a fine opportunity to advertise New Zealand"159. With a catalogue on his Parorangi farm and the New Zealand Romney Marsh Sheep Breeders' Association written in Spanish and English for South American pastoralists and breeders, he met the "leading English breeders on neutral ground" at the exposition. Short took most of the prizes in the classes for which he was eligible, attracting much attention at the show, with the sheep admired especially for their wool ${ }^{160}$.

157 NZM, 16 October 1901, 31 d; 13 November 1901, 38 a; Dominion, 18 April 1913, 8 b; Press, 10 July 1913, 9 d; New Zealand Official Year-Book 1899, Wellington, Government Printer, 1899, 468469; New Zealand Year-Book 1903, Wellington, Government Printer, 1903, 602; D.C.M. Platt, Latin America and British Trade, 1806-1914, London, A. and C. Black, 1972, 261; Gary R. Hawke, The Making of New Zealand: An Economic History, Cambridge (England), Cambridge University Press, 1985, 87; Belich, Paradise Reforged, op. cit., 62, 70.

158 Feilding Star, Feilding, 24 September 1924, 5 a, b; Biographical drafts (complete), MSPapers-7007-06, (a) Mills, Thomas Lewis, 1865-1955: "Ernest Short of Parorangi: Profile of a Progressive, Profitful Pastoralist”, Alexander Turnbull Library, Wellington.

159 Evening Post [hereafter EP], Wellington, 21 July 1909, 3 c.

160 NZF, April 1910, 296; May 1910, 459 a, b, c, d and 460 a; January 1911, 70 a, b; EP, 21 April 1910, 4 c; Press, 10 August 1910, 12 d. 
The New Zealand government, too, sent produce to exhibit at the Grand International Agricultural Exposition in Buenos Aires, including "excellent specimens of apples". New Zealand apples had been sent to Argentina before, in 1896 , but there were no further shipments. The New Zealand produce was put on display in the British pavilion, where the apples "took premier place, and caused considerable surprise by their outstanding excellence". James E. Davenport, a sheep breeder from Christchurch and participant at the exposition, remarked that New Zealand's chief opening in trade with Argentina must be fruit. Argentina was not a fruitgrowing country and New Zealand could send apples and other fruit there in the best condition ${ }^{161}$.

Trial shipments were subsequently forwarded to Argentina after the exposition. Following enquiries from Argentina for 80,000 cases of apples in 1911, the trade, in which J.G. Moore and Company in Buenos Aires (Moore was a New Zealander) bought the apples and distributed them, started with the shipment of 4,999 cases from Nelson between March and May in 1912. The Hawke's Bay Fruitgrowers' Company and the Waitemata Fruitgrowers' Co-operative Society also sent pilot consignments of different apple varieties. In the 1913 season, 27,000 cases went to Argentina, while fewer consignments of apples were sent to Britain that season. The Christchurch Press noted that "at present almost the whole of the apples sent out of the country are going to South America". And in the 1914 season, 60,000 cases were shipped to Argentina ${ }^{162}$.

Apart from increasing trade between New Zealand and Argentina, the other significant aspect of the new fruit trade was the boom in fruitgrowing it brought about in New Zealand. Encouraged as much by exporters as the promise of the South American market, many thousands of hectares in Nelson, Marlborough, Canterbury, Otago, Wairarapa, Hawke's Bay, Poverty Bay, Waikato and North Auckland, including what had been considered marginal land, were opened up and planted from 1910 with leading commercial varieties of apples and pears. Suitable types of apples for the wet climate of Westland, and not susceptible to disease, were planted out also. The Wellington newspaper Dominion reported that since the market in South America had opened up, fruitgrowing in Nelson had made "rapid strides". Bill Benzies, a one-time member of the Apple and Pear Board, remembers people leaving towns and immigrants to the country arriving to take up fruitgrowing. The land given over to this purpose increased in value from a few shillings to $£ 30$ an acre, particularly in Auckland and Nelson - land in Nelson was especially subject to speculation ${ }^{163}$.

161 The Annual Report of the Department of Agriculture, Commerce, and Tourists [hereafter ARDACT], Wellington, Government Printer, 1910, 60, 81; Press, 11 October 1910, 4 c; 14 September 1910,3 d.

162 ARDACT, 1913, 97; Dominion, 4 October 1913, 8 b; Press, 8 December 1913, 3 c; Tacon, op. cit., 15 .

163 Press, 23 April 1913, 3 c; 27 January 1914, 4 d; 29 April 1914, 2 b; 6 July 1914, 10 c; Dominion, 13 March 1914, 5 d; 4 March 1915, 7 d; Bill Benzies, Partners in Production, Wellington, New Zealand Apple and Pear Marketing Board, 1968, 11-17. 
After three years of development, the South American fruit trade suddenly ceased. J.G. Moore and Company cancelled all buying orders in October 1914 and refused to do any more business in New Zealand apples on account of the prevailing financial crisis (although, as will be seen in the discussion on Uruguay, substandard quality and packing also caused the firm to withdraw). Because of the war and trade dislocation, no outlet other than South America for New Zealand's surplus exportable fruit was apparent. The New Zealand Fruitgrowers' Federation therefore urgently petitioned the government to send a special commissioner to South America to try and re-establish the market. In November 1914 the government appointed G.L.Tacon, a fruitgrower in the Motueka district in the South Island, as commissioner to go to Argentina, Uruguay and Brazil for three months to enquire into conditions affecting the then present and future sale of New Zealand fruit in the region and the industry's future in South America ${ }^{164}$.

As sheep raising moved largely away from the pampas after 1900 and was replaced by a rejuvenated cattle and wheat economy, Southern Patagonia became another destination for New Zealanders emigrating to South America in the nineteenth and early twentieth centuries, in spite of its harsh climatic conditions, which had historically hampered European colonization ${ }^{165}$.

\section{SOUTHERN PATAGONIA}

\section{8-1914}

As pastoralists spread across the Southern Patagonian pampas after 1876, New Zealand's entry into the region was epic. Henry Jamieson, a New Zealander from the Mount Cook area in the South Island, who had arrived in Argentina at 18 years of age and spent his early years at Bahía Blanca and Necochea in the Province of Buenos Aires, led a sheep drive from the Province of Río Negro that became a legend in the Province of Santa Cruz for its two years of hardships and endurance popularly called El Gran Arreo de 1888 or The Great Drive of 1888. On completing his famous southward drive, Jamieson established the Estancia MoyAike at the Río Coig ${ }^{166}$.

With this push by pastoralists, Punta Arenas, once a penal settlement, became the centre of what was to be an economically autonomous region, replacing Port Stanley in the Falklands as the hub and haven in Southern Patagonia for ships going to the Pacific ${ }^{167}$. From the 1880 s the Southern Patagonian economy

164 Press, 21 November 1914, 4 b; Tacon, op. cit., 1-2.

165 Scobie, op. cit., 53; Rock, op. cit., 169.

166 Weekly Press, 15 September 1897, 17 c; OW, 31 January 1906, 8 e; Correa and Klappenbach, op. cit., 132; Michael Mainwaring, From the Falklands to Patagonia: The Story of a Pioneer Family, London and New York, Allison and Busby, 1983, 93; José S. Borrero Rivera, "Ovejas para la Patagonia", Todo es Historia 366, 1998, 60.

167 Mainwaring, op. cit., 30. 
consolidated, based on sheep, alluvial gold, seal skins and timber, which, along with immigrants, created other enterprises such as commercial businesses, light manufacturing, banks and frigoríficos ${ }^{168}$. The export of the products of Southern Patagonia from Punta Arenas not only connected the region with Europe, but a wide variety of imported goods arrived in Punta Arenas itself. Therefore, for example, there were six agencies of international shipping companies located in Punta Arenas by 1898, as well as four local shipping companies which worked the small regional ports.

A more specific response to the new opportunities in the region was the formation of the Sociedad Explotadora de Tierra del Fuego in 1893, which, with holdings on the mainland also, grew into the largest sheep-ranching enterprise in Southern Patagonia. The company was instituted in Valparaíso with support from the British merchant house Duncan Fox and Company to run sheep on the grasslands on the island. Then, in the summer of 1893-1894 concessionaire Moritz Braun established the company's first sheep ranch at Caleta Josefina, on the shore of Bahía Inútil ${ }^{169}$. New roading, fencing and buildings were all required. And in 1893 Alexander Allan Cameron, a New Zealander, who had been assisting the company, was appointed administrador (manager) of Estancia Caleta Josefina ${ }^{170}$.

Cameron was born in Otago in 1868 and was educated at Otago Boys' High School in Dunedin between 1881 and 1884 . He was a station manager in the Oamaru district when, at 24 years of age, he decided to go to South America. Arriving at Río Gallegos from Buenos Aires, he worked for Hamilton and Saunders, a British pastoralist firm in Southern Patagonia. Then he and his brother, John, visited Tierra del Fuego and were "impressed with its potentialities"171. Cameron's knowledge of South Island sheep farming aided the extensive and successful pastoral enterprise of Sociedad Explotadora de Tierra del Fuego. In 1897 he imported a batch of Corriedale sheep from James Little in Otago that had been selected by his father, John Cameron ${ }^{172}$. About this period, too, Alexander Cameron may have been responsible for a trade in wool-pressers, wool bales, saddler and harnessing,

168 Gilbert J. Butland, Human Geography of Southern Chile, London, G. Philip, 1957, 57-58; Elsa Mabel Barbería, "El extremo austral sudamericano: ocupación y relaciones de los territorios argentinos y chilenos, 1880-1920", Estudios Fronterizos 33, Mexicali, 1994, 188-189; Mateo Martinic Beros, Historia del Estrecho de Magallanes, Santiago de Chile, Editorial Andrés Bello, 1977, 147-148; Mateo Martinic Beros, "La actividad industrial en Magallanes entre 1890 y mediados del siglo XX", Historia 34, Santiago, 2001, 2.

169 [Sociedad Explotadora de Tierra del Fuego], "Company History (1893-1943), the first fifty years based on the company's official history", online, available at http://patbrit.org/eng/setf/ $50 \mathrm{yrs} . \mathrm{htm}$.

170 [Sociedad Explotadora de Tierra del Fuego], "Company History (1893-1943)", op. cit.; [Sociedad Explotadora de Tierra del Fuego], "Sociedad Explotadora de Tierra del Fuego: Senior Management, 1893-1943", online, available at http://patbrit.org/bil/setf/exec.htm; Mateo Martinic Beros, "Panorama de la Colonización en Tierra del Fuego entre 1881 y 1900", Anales del Instituto de la Patagonia, 4:1-3, Magallanes, 1973, 22.

171 Duncan Cameron to the writer, 2005; Weekly Press, 15 September 1897, 17 e; OW, 29 August 1906, 82 e; Otago Boys' High School Old Boys' Register, op. cit., 26.

172 Pablo Link, El Corriedale, Buenos Aires, Ferrari Hermanos, 1945, 74. 
hardware, as well as more live sheep, which existed briefly between Tĩmaru, Dunedin, Christchurch and Wellington and Chile and Argentina ${ }^{173}$.

While it is not known what motivated Cameron to leave New Zealand for South America, one possibility is that South America was the latest of Eric Richards' "stepping stones" beyond New Zealand in the making of "the Scottish Empire". Recent studies of Scottish migration have revealed the role played by personal testimonies, such as the exchange of personal letters, in sustaining a "culture of emigration". And a notable aspect of Cameron's own emigration was that it led to a wider migration from New Zealand to Southern Patagonia and to securing an "economic niche"174. Alexander Cameron was the eldest son of John Cameron himself an immigrant to New Zealand born in Ardnamurchan in Argyllshire in Scotland, and Mary Ann Reid who was born at Tapanui. She died in 1880 and John Cameron married Isabella Georgina Burbury in Dunedin in 1881. Alexander was accompanied to Tierra del Fuego by his brother John Gemmel Cameron and was later followed by George Reid Cameron, William Reid Cameron, and his halfbrother Donald Raymond Cameron (several of whom were "under-managers" under him), and his half-sister Frances Flora Roseveare Cameron. John Cameron had nine children: seven went to South America either permanently or temporarily ${ }^{175}$.

Cameron's connections did not stop there. William Cameron's fiancée, Nell Gardiner from the Dunedin area, was joined by a family friend, John Campbell Clark of Coroglen on the Coromandel Peninsula, on her way to South America in 1909 to be married. Clark's first job with the Sociedad Explotadora de Tierra del Fuego was to take care of the company's horses and break in horses as "broncobuster". Clark's sister, Ethel, went to Tierra del Fuego also and became governess to Alexander Cameron's children at Estancia Josefina. There, in 1915, she married Walter Joseph Morrison, a company shepherd. Frances Cameron married Robert Ernest Thompson, from Lawrence in Otago, in Punta Arenas. Thompson, a sheep breeder, took a shipment of sheep from Tapanui to South America in 1906 for John Cameron. In 1907 Thompson became Alexander Cameron's "under-manager" on Tierra del Fuego and later manager of other estancias in Southern Patagonia. After

173 [Registrar-General of Births Deaths and Marriages], Statistics for the Colony of New Zealand, Return Showing the General Exports from the Colony of New Zealand during the Year [-], By Authority, Wellington: 1895, 202; 1896, 203; 1897, 187, 191, 200, 204, 205, 219, 225; 1899, 213. One firm in Masterton in the Wairarapa, Donald and Sons Limited, advertised that it commonly exported its wool-presses to the Strait of Magellan, Uruguay, Paraguay, Chile and Argentina, Richard Wolfe, A Short History of Sheep in New Zealand, Auckland, Random House New Zealand, 2006, 68.

174 Eric Richards, "The Last of the Clan and Other Highland Emigrants", in Brooking and Jennie Coleman (eds.), The Heather and the Fern: Scottish Migration and New Zealand Settlement, Dunedin, Otago University Press, 2003, 39; David A. Gerber, "Epistolary ethics: personal correspondence and the culture of emigration in the nineteenth century", Journal of American Ethnic History, cited in Angela McCarthy, "Introduction: Personal Testimonies and Scottish Migration", in Angela McCarthy (ed.), A Global Clan: Scottish Migrant Networks and Identities since the Eighteenth Century, London and New York, Tauris Academic Studies, 2006, 2, 7.

175 [Ann Munro], "British families in Southern Patagonia, Cameron-Reid", online, available at: http://patbrit.org/bil/supp/c0253.htm; [Ann Munro], "Memories of Tierra del Fuego by Frances Flora Roseveare Thompson, 1970", online, available at: http://patbrit.org/bil/supp/c0245-interview.htm. 
Alexander Cameron retired to Buenos Aires in 1915, William Cameron, his family and John Clark left Tierra del Fuego and went to Las Heras in the Province of Santa Cruz where William had the Estancia Cameron ${ }^{176}$.

These New Zealanders entered a relatively new southern British World in Southern Patagonia. By 1906, when sheep farming was established as the main economic activity in Southern Patagonia, the British made up 40 per cent of those employed in the sector in Magallanes, followed by Chileans comprising 39.5 per cent. And while most of the Chileans provided the labour, specialist and skilled areas, such as shepherding, were the preserve of the British and among them, the Scots. Administration and foremen positions and above were almost without exception controlled by the British. Of the 1,001 British immigrants who declared their occupation in the British Consular Registers, 50.8 per cent were either selfemployed or connected with raising stock, and those of Scottish origin were 64.2 per cent. By about 1910 Punta Arenas had a population of about 12,500, which included some 300 British residents, but about 3,000 British people had settled around Magallanes ${ }^{177}$. Ernest Gibson thus wrote in The Field (and reprinted in the Christchurch Press) in 1910 that "[t]he farmers in Tierra del Fuego are nearly all English". Few of them spoke Spanish and their currency was the sovereign. They lived comfortably, and had good houses, and obtained their stores directly from London $^{178}$.

Unsurprisingly, therefore, Southern Patagonian sheep farming progressively followed the British sheep farming experience and method of the broader British World $^{179}$. In 1911, Robert Logan, from Otago, visited Southern Patagonia and found a similarity in the way the estancias were run with Australasian sheep stations ${ }^{180}$. According to one team of scholars, also, there was a correlation between Anglo-Scottish farms, Australian and New Zealand sheep stations and Southern Patagonian estancias. This group -Juan Benavides, Mateo Martinic Beros, Marcela Pizzi and María Valenzuela- advocates the estancia system, or the sheep ranch system, which was based on ownership of extensive areas and organized on an industrial model. The centre of a typical estancia comprised a complex of specialized buildings and installations, including sheep pens, dipping baths, a shearing-shed (called a woolshed in New Zealand), stables, stores and barns, and wood and metal workshops; accommodation for peones; individual dwellings for the families of the administrative staff; and the casa de administración, or "big house", the residence of the manager or owner. And so they find the connection to Australasia apparent in several ways. It exists in

176 Joan Nauta to the writer, 2004; [David Gardiner], "British Families in Southern Patagonia, Morrison-Clark", online, available at: http://patbrit.org/bil/supp/c0255.htm; [Ann Munro], "British Families in Southern Patagonia, Thompson-Cameron", online, available at: http://patbrit.org/bil/supp/ c0245.htm.

177 Grey River Argus, Greymouth, 9 December 1910, 1 c.

178 Press, 30 August 1910, 9 c; also Martinic Beros, Historia de la Región Magallánica. Volumen 2, Punta Arenas, Universidad de Magallanes, 1992, 850.

179 Martinic Beros, Historia de la Región Magallánica, op. cit., II:797.

180 Press, 6 September 1911, 3 c. 
architectural forms, such as the imposing Australasian-styled galpón de esquila (woolshed or shearing-shed), and in the spatial organization of a typical complex, such as in its deliberate hierarchal arrangement of buildings ${ }^{181}$. This Australasian template was replicated by people like John Stewart Milne, an Auckland carpenter, who by 1898 was working on contract erecting buildings on estancias in the vicinity of Puerto Cóndor in newly-colonized Última Esperanza in Andean Patagonia $^{182}$.

The transfer of south British pastoralism took time to adapt to the conditions and demands of the Southern Patagonian pampa. At first, sheep farming suffered practical difficulties arising from the sheer expanse of holdings, the lack of fences, and the outlay required. In due course, sheep farming in Southern Patagonia followed the dictates of the seasons where there was very little day in winter and very little night in summer - and paralleled the farming calendar in New Zealand $^{183}$. To one Southern Patagonian estanciero who spent 19 years in New Zealand, admittedly, there was one difference between the two contexts. Sheep farming was "a slavish life" in New Zealand because it was a very mountainous country and everything had to be done on foot with dogs ${ }^{184}$. Even Thomas Currie, a writer for the Christchurch Press visiting the region, thought Southern Patagonia physically resembled the southern parts of Canterbury and Otago and that it was only natural that the same methods should be applicable to both. He said English methods, however suitable to small flocks in Britain, were not suitable for Southern Patagonia where many estancias shore 100,000 sheep or more; "and while the size of the holdings at once suggests Australia, the climate is very different, and one hardly hears of any Australians in this part of the world". The manager who tried to run his estancia on the model of a New Zealand sheep farm, he continued, faced many difficulties, "and must be content to remain a good way from his goal. But it will at once be seen how valuable is the help of a man who knows by actual experience just what that goal is. This is what the Englishman, as distinct from the New Zealander, so often fails to grasp"185.

Not only did Englishmen have this apparent trouble. Currie also observed that "[t]he Argentine or Chilian peon is not to be compared to the New Zealand farm hand", a fact that caused many difficulties for a manager trying to run an estancia on the New Zealand sheep farm model. Therefore New Zealanders were sought after in Southern Patagonia. Indeed, Currie was advised in Punta Arenas that new-comers

181 Juan Benavides, Mateo Martinic, Marcela Pizzi and María Paz Valenzuela, Las estancias magállanicas: un modelo de arquitectura industrial y ocupación territorial en la zona austral, Santiago de Chile, Editorial Universitaria, 1999, 20, 24-27, 59-69, 73-84. Also [Duncan Campbell], "The Estancia System: a distinctive feature of Southern Patagonia", online, available at: http:// patbrit.org/eng/ranchers/estancias.htm.

182 Milne, John - Punta Arenas, Chile - Carpenter 1902, 4388, Series BBAE 1569, Box 141, Archives New Zealand, Auckland; Bertha M. Norris, The Milnes and Choyces of Early Auckland, Auckland, J.R. Milne, R.S. Milne and J.S. Kidd, 1991, 18-24.

183 Mauricio B. Helman, Explotación del Ganado Lanar en la Patagonia, Buenos Aires, Editorial Sudamericana, 1941, 29; Press, 30 August 1910, 9 c.

184 Donald McCorquodale, The Argentine Revisited. 1881. 1906, Glasgow, W. \& R. Holmes, 1909, 93.

185 Press, 5 April 1913, $9 \mathrm{~g}$. 
looking for employment should pretend that they were New Zealanders. He said that New Zealanders "will find many of his countrymen in positions of administration in the companies which own many, if not most, of the estancias of these parts". They were not "merely the managers", but took "a leading part in the direction of the affairs of the companies". And he also asserted that as "the colonial secures a position he may be greeted by 'Oh, so you're another sanguinary New Zealander. The thing I can't understand is that even if an Englishman gains experience here for a hundred years he's not as good as a newly-arrived New Zealander'".

Allowing for parochialism and exaggeration, there is a good deal of truth in the statement. Nothing else seemed to compensate for the absence of that process known as being "broken in" on a New Zealand sheep station. The South Island high country sheep station was very extensive and included a range of variations in "topography, climate and character". Situated at high altitudes, combined with the nature of topography, its carrying capacity was low and "extremely vulnerable" to severe climatic hazards and varying soil quality. There were, as a consequence, often wide seasonal variations in lambing percentages and stock losses. These factors had a considerable influence on management practices, such as the need for careful monitoring of the number of sheep put on to get high production per acre, because overstocking tussock grassland could result in its long-term damage ${ }^{186}$.

Hence New Zealand specialists, as well as others from Britain and Central Chile, were brought to Magallanes to farm the specialized sheep breeds adapted to the marginal conditions of Southern Patagonia ${ }^{187}$. New Zealanders were already spearheading other advances in sheep farming on the Falkland Islands and probably were known for this: Wickham Bertrand, a New Zealand farmer, introduced a strong tobacco dip to fight scab there. In 1895 three New Zealanders were appointed as the stock inspector and assistant sub-inspectors to administer an ordinance to eradicate scab. Then in 1896 several farmers imported a small quantity of cock's-foot grass seed from New Zealand that was suited to the islands' soil deficiency in lime ${ }^{188}$. And therefore, Alexander Cameron was recognized in the Censo Jeneral of 1908 as possessing a deep knowledge of operating sheep farms and as being an innovator because of the improvements that he had introduced to the Sociedad Explotadora de Tierra del Fuego operation ${ }^{189}$. Similarly, New Zealander Hugh Dixon went to Southern Patagonia in 1898 as the region's first wool-classer ${ }^{190}$.

186 F.L. Ward, High Country Sheep Farming in the South Island, etc., Wellington, New Zealand Meat and Wool Board's Economic Service, 1960, 7; R. Ogilvie Buchanan, The Pastoral Industries of New Zealand, London, G. Philip and Son Ltd., 1935, 44-45.

187 Sergio Vergara Quiroz, “La 'Fiebre del Oro' en Magallanes, 1885-1895: Imán Demográfica y Factor de Capitalización”, Revista Chilena de Historia y Geografía 162, Santiago, 1996, 124.

188 V.F. Boyson, The Falkland Islands, Oxford, Clarendon Press, 1924, 201, 205-206, 208; Press, 15 July 1895,3 c; 17 July 1895,5 c.

189 Lautaro Navarro Avaria, Censo Jeneral de Población, Edificación, Industria, Ganadería $i$ Minería del Territorio de Magallanes. Volumen 2, Punta Arenas, Talleres de la Imprenta E1 Magallanes, 1908, 113.

190 [Duncan Campbell], “The Magellan Times”, Death Announcements 1914-1918 (incomplete), Hugh Dixon, Punta Arenas, 14 October 1915", online, available at: http://patbrit.org/bil/mt/obit-191x.htm. 
Other developments took place in the economy of Southern Patagonia to cause the New Zealand-Southern Patagonian relationship to grow closer. The local market for mutton had been limited relative to the huge flocks of the pampa, while sheep above seven years of age were uneconomic wool producers. Pressure from the increase in sheep numbers and the inability to absorb them locally saw investment move from small-scale refrigerating plants and tallow works to frigoríficos. In 1903 the South American Export Syndicate, formed by British and Magallanes capital, bought the tallow works at Río Seco, north of Punta Arenas, built the first frigorífico in Southern Patagonia, and began processing in 1905. It had a yearly capacity for 200,000 head of mutton and by 1906 it was exporting over 100,000 carcasses, as well as a trade in by-products such as casings and dried blood ${ }^{191}$.

The participation of the Southern Patagonian frigorificos in the international market place caused them to demand a better quality of meat ${ }^{192}$. Therefore in 1905 , the Sociedad Explotadora imported ten Corriedale sheep from New Zealand destined for Santa Cruz ${ }^{193}$. The Corriedale, together with Romney Marsh sheep, continued to be imported from New Zealand because of their good wool and meat ${ }^{194}$. In 1908 Ernest Short sold five Romney Marsh sheep to W.M. Dean at Río Gallegos 195. And in 1910 Menéndez Holdings imported New Zealand Corriedale ${ }^{196}$. Accordingly, the quality of flocks in Southern Patagonia began to show an impressive statistical record of improvement - and among the reasons offered was "the importation of pedigree stock, principally from New Zealand, taking a high place"197.

There were, however, impediments to this promising trade (which besides sheep also included wool-presses, a wagon and resene) ${ }^{198}$. Trade with Punta Arenas was frustrated after the sinking of the New Zealand Shipping Company ship Mataura in the Strait of Magellan in January 1898. After this mishap the company decided its ships were to go around Cape Horn. Even though Punta Arenas was the distribution centre for a vast region that keenly sought the kind of goods New Zealand could supply, any goods and passengers destined for Punta Arenas had to be transshipped from Montevideo at added expense. The sheep that had been brought into Southern Patagonia had been done so only by wealthy sheep farmers ${ }^{199}$. New Zealand ships that ventured into the Strait of Magellan were prohibitively expensive because of the insurance on the vessel and its cargo, as

191 Press, 15 May 1909, 5 e; Butland, op. cit., 65; Benavides, Martinic, Pizzi and Valenzuela, op. cit., $45,47$.

192 Chile Austral, Punta Arenas, 26 de febrero de 1909, 4 c.

193 Helman, op. cit., 31.

194 Chile Austral, 26 de febrero de 1909, 4 c; EP, 8 May 1912, 11 d.

195 [New Zealand Romney Marsh Association], New Zealand Romney Marsh Flock Book. Volume 4, Palmerston North and Feilding, 108-109.

196 Pheasant, op. cit., 135.

197 Butland, op. cit., 69.

198 Navarro Avaria, op. cit., 354; [Superintendencia de Aduanas], Estadística Comercial de la República de Chile correspondiente al año de: 1908, 247, 1909, 284, 1910, 314, 316.

199 Waters, op. cit., 45-46; EP, 8 May 1912, $11 \mathrm{~d}$. 
well as the high cost of freighting live animals ${ }^{200}$. Another obstacle -more localmay have affected the future of the trade in sheep to some extent. New Zealand merino rams were sent to Santa Cruz for breeding, but were later discarded because there was difficulty in breeding a constant type, where the lambs in each successive generation became smaller in body in spite of an improvement in wool quality ${ }^{201}$.

New Zealanders brought innovation in another sector of the Southern Patagonian economy as well. After the finding of alluvial gold in 1868 near Punta Arenas, goldmining in the region had continued to rely on often rudimentary methods, such as pans and sluice-boxes. As miners directed more attention to the rivers, especially on Tierra del Fuego, the Southern Patagonian gold-mining industry became more mechanized and organized in order to work the gravels ${ }^{202}$. H.W. Edwards, a contemporary, considered this approach started in 1902 with the arrival of Archibald Cameron and James Musgrave, both from New Zealand where they had experience in dredging ${ }^{203}$. After prospecting the country, including Bahía Sloggett, Cameron and Musgrave formed a company to operate on the Río Santa María, in the vicinity of the settlement of Porvenir ${ }^{204}$. The advent of Cameron and Musgrave occurred after a second dredge boom in Otago that peaked in 1899-1900. Although the dredge had been developed and improved in Otago since the 1860s, William Cutten's tailings-elevator in 1894 revolutionized the dredging industry because it enabled dredges to extend their operation to river banks and terraces ${ }^{205}$. The dredge boom stimulated engineering shops in Dunedin and gave Otago a brief period of prosperity, even if both production of gold and the number of working dredges fell after $1902^{206}$.

A large number of men gained experience in the working of dredges during the boom, and among them skilled men were drawn "to initiate and develop the dredging industry" overseas, including South America ${ }^{207}$. New Zealand dredgemen and winchmen headed to Southern Patagonia once a boom, based on the launch of new companies to dredge-mine on Tierra del Fuego, occurred about 1907. They

200 Dominion, 4 July 1912, 4 g; Press, 17 July 1913, 3 c.

201 Helman, op. cit., 30; Mainwaring, op. cit., 224.

202 TNZMR, 11:2, 16 September 1907, 70; Navarro Avaria, op. cit., 167; R.A.F. Penrose, "The Gold Regions of the Strait of Magellan and Tierra del Fuego", Journal of Geology 16, Chicago, 1908, 687-688; Butland, op . cit., 61-63; Vergara Quiroz, op. cit., 108-109.

203 H.W. Edwards, "Mining in the Straits of Magellan", Engineering and Mining Journal 92, New York, 1911, 1091.

204 Padrón Minero de los Territorios Nacionales 1906, División de Minas, Geología e Hidrología, Sección de Geología, Mineralogía y Minería, Anales del Ministerio de Agricultura, Tomo II, Número 1, "Distrito Bahía Sloggett y Moat, Cateos 1900-1905", Buenos Aires, 1907, hoja 137. David Guevara forwarded this reference to the writer.

205 [Mines Departament] John McCombie, in Three Prize Essays on the Present Condition and Future Prospects of the Mineral Resources of New Zealand, Wellington, Government Printer, 1907, 291.

206 T.J. Hearn and R.P. Hargreaves, The Speculators' Dream: Gold Dredging in Southern New Zealand, Dunedin, Allied Press, 1985, 52, 78; Erik Olssen, A History of Otago, Dunedin, McIndoe, 1984, 125-127.

207 [Mines Departament] Robert McIntosh, in Three Prize Essays, etc., op. cit., 89. 
included Norman Wakefield, G.C. Troy (formerly master of the Electric Number 1 in Otago and in charge of the Río Oscar dredge), Booth (of Southland), Brand (Kelso), Burton, Gunn (Coalcreek), Jeffries (Cromwell), Lister (Alexandra), Moffat (Waikaia), David Robertson (Roxburgh) and C.J. Silk among others. A visitor to the goldfield was Dunedin dredge builder John McGregor of the Otago Foundry ${ }^{208}$. While relatively ephemeral, the goldminers were nevertheless part of a wider movement of New Zealanders to the Southern Cone republics. Southern Patagonia, along with Platine Argentina and the central and northern regions of Chile with their relatively large British populations, had attracted New Zealanders. However, one Southern Cone country -Uruguay- despite an influential British presence and a direct shipping link with New Zealand, failed to draw New Zealanders to the same extent.

\section{URUGUAY}

1894-1914

New Zealand had a direct link with Uruguay once New Zealand Shipping Company ships began calling into Montevideo from 1894 and Shaw Savill and Albion Company ships from $1895^{209}$. If Montevideo was unsuccessful in outbidding Buenos Aires for regional primacy after independence, it was nonetheless situated along an oceanic sea lane at the mouth of the Río de la Plata. By 1851 it had a coaling station as steamships replaced sail on the ocean routes and the demand for coal and the need for coaling stations increased ${ }^{210}$. Nearly all of the 16 coaling stations in Latin America were operated by British and stocked with Welsh coal ${ }^{211}$.

Even so, bunkers were just one facet of a long British presence in Uruguay, which dated back to when the Spanish colony was established on the Banda Oriental (eastern bank of the Río de la Plata) and illicit commerce in contraband hides and manufactures existed. In 1864 Uruguay received its first British loan, and British railway and utility enterprises can be traced to 1865-1875. By the 1900 s the economic infrastructure of Uruguay was "concentrated in English hands". British capital and enterprise dominated utilities and insurance, and occupied the leading position in banking, meat processing and ranching ${ }^{212}$.

208 OW, 29 August 1906, 82 g; TNZMR, 11, 2, 16 September 1907, 70-71, 11, 8, 16 March 1908, 349, 12, 1, 17 August 1908, 47; R.S.M. Sinclair, Kawarau Gold, Dunedin, Whitcombe and Tombs, 1962, 128.

209 Press, 20 November 1894, 1 a; 21 November 1894, 4 e; 2 August 1895, 1 b.

210 W.E. Minchinton, "British Ports of Call in the Nineteenth Century", The Mariner's Mirror 62:2, London, 1976, 149-150; "Daily Alta California", Shipping Intelligence, SS Northerner, Port San Francisco, July 8, 1851, online, available at: www.maritimeheritage.org/PassLists/no070751.html.

211 Albion, op. cit., 370.

212 Peter Winn, "British Informal Empire in Uruguay in the Nineteenth Century", Past and Present 73, Oxford (England), 1976, 100, 109-116. 
This British domination in Uruguay encompassed New Zealand shipping as well. In Montevideo the agents for the New Zealand Shipping Company and Shaw Savill and Albion during the 1890s were Wilsons, Sons and Company Limited, London-based merchants and proprietors of coal depots in Saint Vincent, Pernambuco, Bahia, Rio de Janeiro, Santos, Buenos Aires and La Plata, with branch offices in Cardiff and Barry. By 1911 Mann, George Depots were the new agents to New Zealand shipping. They were coal importers, steamship and general commission agents, importers of "best description" South Wales coal, and had branch offices in Buenos Aires, La Plata, Rosario and San Gerónico in Córdoba ${ }^{213}$.

Regardless of their agents, the companies' various steamships traversed the Pacific fortnightly through "a long stretch of cold water from New Zealand to the Horn"214. Cape Horn was notoriously dangerous. The Shaw Savill and Albion ships Dunedin (of refrigeration fame) and Marlborough were lost without trace in 1890 , believed to have collided with icebergs after rounding Cape Horn. Nonetheless, the New Zealand Shipping Company was not deterred in redirecting its ships around Cape Horn after the Mataura sank in the Strait of Magellan in $1898^{215}$. From Cape Horn, the ships then made their way up the Patagonian coast to Montevideo.

Since contracts stipulated how long a voyage was to take, the length of time spent in port depended on how far ahead or behind schedule ships were, or more precisely, the time it took to load coal. The 1905 and original All Blacks rugby football team took the opportunity to explore exotic Montevideo en route to their famous tour of Britain. Three years later, the Raymond family of Southland, travelling on the Rimutaka in 1908, spent a day in Montevideo having lunch at a fashionable hotel, doing shopping (despite language difficulties) and sightseeing (the cemetery and admiring the city's ornate frontages). In 1911, however, the New Zealand Shipping Company's Ruahine was expected in Montevideo at 1 p.m. on 12 September, its passengers to embark at 5 p.m., and then sail that night. In 1914 L.H. Barford from New Zealand had a few hours with his brother, N.P. Barford, who came from Buenos Aires to meet up with him, before the ship departed again ${ }^{216}$.

Passengers could break their journey and spend time looking around the Plata region "en passant", as did Aucklanders R.H. Abbott and his daughter in 1913, who spent several weeks in Uruguay, Argentina and Brazil on their way to England. Most disembarking passengers, however, transshipped by river steamer to Buenos Aires. Mabel T. Douglas, from Auckland and daughter of the editor of the New Zealand Herald, arrived in 1912 on the Ruapehu and was going to be immediately married in the Hurlingham Church in Buenos Aires to Harry Steele, formerly of Wellington. And Captain Amundsen, passenger on the Remuera in

213 Montevideo Times [hereafter MT], Montevideo, 4 January 1891, 2 f; 15 January 1895, 2 d; 5 January 1911, 2 c; 24 August 1911, 4 a.

214 MT, 20 May 1914, 1 a.

215 Waters, Shaw Savill Line, op. cit., 67; Waters, Clipper Ships to Motor Liner, op. cit., 45-46.

216 Supplement to the Southland Times, 27 August 1908, 1 a; MT, 12 September 1911, 1 f; 27 May 1914, 7 c; Christopher Tobin, The Original All Blacks 1905-06, Auckland, Hodder Moa Beckett, 2005, 28; Bob Howitt and Dianne Haworth, 1905 Originals, Auckland, HarperSports, 2005, 39-40. 
1912, was continuing on to Buenos Aires where he was going to stay and prepare the account of his South Pole feat ${ }^{217}$.

Yet, most New Zealanders seem to have bypassed Uruguay, even though between 1875 and 1889 it was a target for some 76,000 immigrants - mainly Italian, Spanish, French and some British and Germans ${ }^{218}$. Later known New Zealand settlers were the two sons of William Ware of Auckland, who about 1904 had an estancia some 800 kilometres inland from Montevideo. And Arthur White left Palmerston North in the North Island in 1909 and used Montevideo as a base for his evangelical missionary work in the city and surrounding countryside ${ }^{219}$. However, in 1885 Sir John Hall and Captain Baldwin found the pasture unsuitable for sheep in spite of the attractive and park-like countryside around Montevideo. Furthermore, scab was rife because no law existed to control it. Possibly the greater obstacle in New Zealanders' minds was that Uruguay seemed ultimately politically intractable. An uprising by Uruguayan politician Aparicio Saravia in 1903 caused the Southland Times to cynically comment "Uruguay is a South American Republic, which is equivalent to saying that periodical revolutions are to be expected". There was also the question of personal safety as British estancieros lived with destruction brought by the civil wars. Baldwin and Hall took the precaution of carrying revolvers while in Uruguay, and noticed managers of estancias doing the same, although the managers rarely had occasion to use them. Furthermore, the disappearance of New Zealanders David Missonne and Mr Merryvale could only have fuelled public uncertainty with regard to Uruguay since their families in New Zealand had not received any word from them in over a year after their arrival in Montevideo in $1910^{220}$.

For all of Uruguay's problems, New Zealand, stimulated by the new steamship connection, began to do business with Uruguay. From 1895 up to the First World War, Uruguay imported live animals, produce, grass seed and trees, manufactures, ironmongery, gold, and consumer, agricultural and fancy goods from New Zealand. In fact, the New Zealand Official Year-Book stated in 1917 that Uruguay was among New Zealand's most regular foreign customers, along with France and Belgium, until the First World War disrupted trade in $1916^{221}$. In general, the slow

217 New Zealand Mail, 20 July 1904, 66 c; Dominion, 10 December 1913, 3 d; MT, 5 March 1912, $1 \mathrm{~d} ; 21$ May 1912, $1 \mathrm{f}$.

218 Benjamín Nahum, Manual de Historia del Uruguay 1830-1903. Volumen 1, Montevideo, Ediciones de la Banda Oriental, 1996, 141-142. Consulate - General of Uruguay, The Republic of Uruguay, South America, London, Edwardf Stanford, 1883, 3, 62.

219 New Zealand Mail, 20 July 1904, 66 c, d; Marsh, op . cit., 27.

220 Mulhall, op. cit., 339; Press, 2 December 1885, 5 f; 8 November 1911, 7 f; Southland Times, 20 March 1903, 2 i.

221 [Registrar-General of Births Deaths an Marriages] and [Government Statistician], Statistics for the Colony of New Zealand and Statistics for the Dominion of New Zealand, Return Showing the General Exports for the Years from 1895 to 1914, By Authority, Wellington. 1895, 219, 1896, 183, $190,195,1897,187,1898,189,1899,194,224,1900,197,217,227,1901,204,1902,207,216,226-$ $227,238,1903,214-215,219,229,234,236-237,249,1904,228-229,243-244,250,1905,227-228$, $231,233,236,243-244,249,263,1906,233-234,239,249-250,256-257,260,264,268,272,276$, $1907,237-238,251,253,261-262,273-275,1908,140-141,148,157,164-165,168,177,179,1909$, $141,165,170,175,177-178,188,1910,142-143,147,158,163,168-171,174,180-181,183,191$, $194,1911,153-154,158,160,162,173,175-177,182,184-185,190,198,200-201,203,1912,159$, $164-165,167,173-174,177,180,187,190,196,203,205-206,220$, 1913. Volume 2, 136-137, 142, 
increase in domestic production of textile, clothing, shoes and processed foods by Uruguayan industry may explain the trade with New Zealand. Or, alternatively, articles such as books, toys, sauces, preserves and stationery may have been imported from New Zealand by wholesalers who were a predominant component in the Uruguayan economy, and who saw Montevideo well placed to do business in Argentina and Brazil. Certainly, these wholesalers typically dealt in a wide range of goods and had a large turnover 222 .

Extensive business saw the appointment of a Uruguayan official representative in New Zealand. César Montero Bustamante became Uruguay's consul in Wellington in 1910, but he decided to return to Uruguay two years later, apparently out of frustration in not being able to expand trade further between New Zealand and Uruguay. There was a great imbalance in trade between both countries: between 1909 and 1914 only £263 worth of imports from Uruguay comprising medicinal preparations, unenumerated provisions and five live sheep passed New Zealand customs ${ }^{223}$. Another hurdle was that, despite the trading opportunities offered by Uruguay, New Zealand ships loaded with cargo for Montevideo could not refill the space left in Montevideo for the leg to Britain 224 . And during discussions with E. Cooper and Son, commission and shipping agents in Montevideo, Commissioner Tacon was informed that it was high freight costs that inhibited what might otherwise be "much good business from New Zealand in potatoes, oats, \&c., as well as apples". The firm was "anxious to foster trade with New Zealand, and, as climatic seasons and conditions are similar, believe [there are] great possibilities in many things which are not or cannot be grown successfully in Argentine [sic] and Uruguay"225.

Notable in New Zealand's trade with Uruguay was the export of live sheep, which arose from Uruguay's quest to improve the strain of its flocks. Until the second half of the nineteenth century, rural Uruguay had remained essentially unchanged from the colonial era. It was characterized by civil wars, self-reliant gauchos, undefined possession of land and extensive estancias, paternalism, and production of low-value hides and jerked meat ${ }^{226}$. However, certain new factors

$150,152-153,156,159,166,168,174,181-182,184-185,189,200,1914$. Volume 2, 22, 29-31, 40, 49-50, 57-58, 70, 78, 97, 132 [hereafter New Zealand Statistics]; New Zealand Official Year-Book 1917, Wellington, Government Printer, 1917, 282.

222 Hubert C. Herring, with the assistance of Helen Baldwin Herring, A History of Latin America from the Beginnings to the Present, $3^{\text {rd }}$ edition, New York, Knopf, 1968, 5-6, 791; Emilio Boix, Estudio Comercial sobre la República Oriental del Uruguay. Segunda Parte, Madrid, Imprenta del Ministerio del Estado, 5-6.

223 New Zealand Statistics, Return Showing the General Imports into the Dominion of New Zealand during the Year 1909, 114; 1911, 39; 1913. Volume 2, 108; 1914. Volume 2, 159.

224 Series EA $161 / 419 / 1$ pt 1a, "Appointment of Uruguayan Consuls at Wellington 1910-1953", Ministry of Foreign Affairs and Trade papers, Archives New Zealand, Wellington; EP, 19 June 1912, $10 \mathrm{~d}$.

225 Tacon, op . cit., 11.

226 Russell Fitzgibbon, Uruguay: Portrait of a Democracy, London, G. Allen and Unwin, 1956, 74; José Pedro Barrán and Nahum, "Uruguayan Rural History", Hispanic American Historical Review 64:4, Durham (North Carolina), 1984, 659; Juan A. Oddone, "The Formation of Modern Uruguay, $c$. 1870-1930", in Bethell (ed.), The Cambridge History of Latin America. Volume 5, Cambridge (England) and New York, Cambridge University Press, 1986, 453-454. 
advanced the development of Uruguay. Following the Guerra Grande (1839-1852) -a Uruguayan civil war in which Argentina, Britain and France became involveda new ranching and commercial elite of recent European origin emerged, centred on the littoral and southern parts of Uruguay 227 . With the post-war period also came the beginning of what Uruguayan historians José Pedro Barrán and Benjamín Nahum call the wool cycle. Wool production became established in Uruguay in the decade 1860-1870, although cattle retained their importance 228 . The wool industry gave the land and sheep a new value through their connection to the world market which cattle, linked to Brazilian and Cuban demand for jerked meat to feed slaves, did not match. And as sheep farming became a capitalist enterprise certain practices changed, especially the introduction of wire fences to prevent freeranging by stock $^{229}$. The benefit of fences was proven at the Wool and Woollen Industries Exhibition at the Crystal Palace in London in 1881 where Uruguayan wool, placed beside Australasian wools, won prizes "due to care and to judicious methods of crossing the breeds" 230 . A decade earlier, too-during one of the major Uruguayan civil wars of the nineteenth century, the so-called Revolución de las Lanzas (1870-1872) - the Asociación Rural del Uruguay was formed by a small group of powerful and "progressive" landowners and some of the urban middle class to promote landowners' interests ${ }^{231}$.

Wool provided much of the basis for economic development. As Uruguay's most important single export item after 1884, it had been adversely affected by declining stocks and falling world prices during 1890-1891232. Nevertheless, by 1900 output had increased to two kilos a head and the wool export was 20 million kilos annually and made up 35-40 per cent of the country's exports ${ }^{233}$. There was continued improvement in the quality of wools by cross-breeding with American Vermonts and Australian merinos imported from Australia, Argentina, the United States and New Zealand ${ }^{234}$.

Statistics for the Colony of New Zealand indicates that the exportation of New Zealand sheep to Uruguay began in $1896^{235}$. However, despite performing well and producing the renowned "Montevideo wool", the merino was unsatisfactory because of its need for high country and short grass, which were not characteristics

227 Winn, op. cit., 113; Ana Inés Zerbino Vanrell and José Víctor Zerbino Vanrell, Antiguas Estancias del Uruguay, Montevideo, J.L. Goyena Gomensoro, 1997, 7; Mario Dotta, Duaner Freire and Nelson Rodríguez, El Uruguay Ganadero, Montevideo, Ediciones de la Banda Oriental, 1972, 64.

228 Barrán and Nahum, op. cit., 659-660, 666-673.

229 Dotta, Freire and Rodríguez, op. cit., 79; Nahum, op. cit., 185.

230 Consulate-General of Uruguay, op. cit., 76-77.

231 Raúl Montero Bustamante and Luis Giordano, Criadores del Uruguay: Cincuentenario de la Fundación de los Registros Genealógicos de la Asociación Rural del Uruguay, Montevideo, A.R.U., Imprenta Germano-Uruguaya, 1937, 51; Dotta, Freire and Rodríguez, op. cit., 68; Aníbal Barrios Pintos, Historia de la Ganadería en el Uruguay, 1574-1971, Montevideo, Biblioteca Nacional, 1973, 197; Nahum, op. cit., 152-153.

232 Oddone, op. cit., 464.

233 Nahum, op. cit., 256.

234 Revista de la Asociación Rural del Uruguay, Montevideo, 31 de diciembre de 1906, 921.

235 New Zealand Statistics, Return Showing the General Exports from the Colony of New Zealand during 1896, By Authority, Wellington, 1897, 190. 
of the Uruguayan pampa. For their part, too, the Shropshire, Oxford Down, Hampshire and other sheep breeds were popular from 1904, but were abandoned after 1908 because they did not improve wool quality ${ }^{236}$. On the other hand, though, the Romney Marsh and Lincoln became the principal breeds imported because of these cross-breeds' successful adaptation to the Uruguayan countryside and the growing market demand for fine cross-bred wool. Furthermore, they were favoured because of the development of the freezing works industry. The La Frigorífica Uruguaya, the newly-built and first Uruguayan frigorífico, slaughtered 100,432 sheep in its first season of 1904-1905, paying a single price 40 per cent higher than that obtained from tallow works ${ }^{237}$. Indeed, sheep breeders in the littoral were encouraged by the possibility of exporting sheep meat, and began to cross merinos with English sheep breeds to produce a dual-purpose breed ${ }^{238}$.

At the Mercedes show in the Departamento de Soriano in 1905 organized by the Asociación Rural del Uruguay, therefore, estanciero Hilario Helguera encouraged Uruguayan estancieros to use New Zealand sheep for cross-breeding purposes. He said that Uruguayan meat had to equal that of other meat on sale on the London market in content and high quality, and cited New Zealand, along with Australia and Canada, as having understood the need for excellence and as having sought out different cross-breeds in recent years ${ }^{239}$. In 1909 also, readers of the Revista de la Asociación Rural del Uruguay were informed that the Romney Marsh was a popular sheep for cross-breeding and that it had been widely used in New Zealand with "excellent results" 240 .

In at least this sector of the economy, therefore, Uruguay looked upon New Zealand primarily as a model to aspire to rather than as a competitor. More generally, also, New Zealand made the news in Uruguay - its technical achievements, exhibitions, sales successes in London and export statistics were all reported as proselyte lessons for producers ${ }^{241}$. This interest in New Zealand even extended to the Faculty of Agronomy's Universal History course in 1911 on the Comtemporary Age in wich New Zealand was to be studied in the context of the British Empire ${ }^{242}$.

The attention given to New Zealand related to a period fertile in ideas and initiatives in rural Uruguay. They were linked to wider socioeconomic reforms implemented under President José Batlle y Ordóñez, where the agricultural sector was also transformed. The period 1907-1912 stands out as one of the high points in

236 Barrios Pintos, op. cit., 189, 221.

237 Juan Ángel Álvarez Vignoli, "Evolución Histórica de la Ganadería en el Uruguay”, Revista del Instituto Nacional de Agronomía, Montevideo, 1917, 84; Dotta, Freire and Rodríguez, op. cit., 90; M.H.J. Finch, A Political Economy of Uruguay since 1870, London, Macmillan, 1981, 135.

238 Juan P. Barriola, cited in Barrios Pintos, op. cit., 221; Álvarez Vignoli, op . cit., 83.

239 Anales de la Asociación de Ganaderos, año 1, No 4, Montevideo, 15 de octubre de 1905, 238; Barrios Pinto, op. cit., 232.

240 Revista de la Asociación Rural del Uruguay, № 10, octubre de 1909, 889.

241 Revista de la Asociación Rural del Uruguay, 24 de diciembre de 1906, 921; 10 de octubre de 1909, 425, 784-786; 10 de octubre de 1911,778; 2 de febrero de 1912, 88; 4 de abril de 1912, 255; 6 de junio de 1912, 422, 424; 10 de octubre de 1913, 750; Alfred Ramos Montero, Manual de Ganadería y Agricultura, Montevideo, A. Barreiro y Ramos, 1911, 133, 682.

242 Agros, Montevideo, 3 y 4, agosto y septiembre 1911, 68. 
the history of the country's livestock industry, which agronomist Juan Ángel Álvarez Vignoli likens to that of 1870-1880. Agriculture was fostered: for example, in upgrading animal breeds for the frigorificos, technicians needed to be trained to promote improvement and methods and help landowners and agriculturists; faculties of Agronomy and Veterinary Science, four research and education agronomical stations, and a congress to represent the aspirations of the rural sector were all established; and legislation to prevent all epizootic diseases in livestock and create rural credit facilities was passed ${ }^{243}$.

As significant, a six-man Uruguayan commission of agronomists, which had been sent abroad by the Uruguayan government to gather information on the pastoral, agricultural and livestock industries of Europe, Australia and North America "to advance the political, social and economic interests of their country", as well as "to benefit the agricultural and pastoral condition of their country", arrived in New Zealand in 1912. The commissioners, Carlos Praderi, Juan Ángel Álvarez Vignoli, Hilario A. Urbina, Jorge Mullin, Carlos M. Saralegin and Samuel Moreira Acosta, were all higher degree students in their early to mid twenties. They spent twelve days in New Zealand, escorted by César Montero Bustamante, and J. Duncan from the Agricultural Department. During their brief stay, they fitted in visits to private farms, the Belfast freezing works in Christchurch, Lincoln Agricultural College, the Gear Meat Preserving and Freezing Company's works at Petone (near Wellington), the Petone Woollen Mills at Korokoro, Ernest Short's stud farm at Armadale and other nearby stud farms. On returning to Uruguay, the commissioners were well received. The Agros, publication of the association of agronomy students at the Instituto Nacional de Agronomía, wrote that their findings were awaited since they would find the right environment in Uruguay to develop their good ideas and "brave efforts" 244 .

As part of this ferment in Uruguayan agriculture, therefore, Ernest Short sent a first consignment of 31 Romney Marsh sheep to Uruguay in 1907. Five years later, in 1912, the first New Zealand Corriedale sheep were imported into Uruguay. And then in 1914 Adolfo Shaw bought at public auction the first Corriedale ram imported from New Zealand by A.W. Lade 245 .

243 Romero Pérez Antón and Carlos Zubilla Barrera, “José Batlle y Ordóñez, un populismo temprano", in Marcos Álvarez García, Líderes politicos del siglo XX en América Latina, Santiago de Chile, Lom ediciones, 2007, 40, 45-47; Faraone Roque, Introducción a la Historia Económica del Uruguay (1825-1973), Montevideo, Editorial Arca, 1974, 79-80; Nahum, Manual de Historia del Uruguay 1903-1990. Volumen 2, Montevideo, Ediciones de la Banda Oriental, 1996, 2, 55; Agros, 3 y 4, agosto y septiembre de 1911, 41; Montero Bustamante and Giordano, op . cit., 103, 105; Koebel, op. cit., 258.

244 NZF, April 1912, 436, plate section, "Visitors from Distant Fields: The Special Commission of Agricultural Engineers from Uruguay"; Dominion, 26 February 1912, 8 d; 27 February 1912, 8 c; 2 March 1912, 8 c; 6 March 1912, 8 b; 8 March 1912, 2 c; 9 March 1912, 8 c; ODT, 27 February 1912, 5 g; Press, 28 February 1912, 12 c; 29 February 1912, 8 e; 1 March 1912, 3 d; Revista de la Asociación Rural del Uruguay, 6 de junio de 1912, 423; Agros, Segunda Época - Año 1:1, julio de 1912, 7.

245 Ramiro Tourreilles and La Propaganda Rural, "Corriedale: la Labor de los Visionarios que la Transformaron en la Raza Mayoritaria del Uruguay", Corriedale Anuario 2003, Montevideo, Sociedad de Criadores del Corriedale del Uruguay, 44, 46; Barrios Pintos, op. cit., 189. 
Besides sheep, New Zealand's thriving trade with Uruguay included apples. In assessing whether Uruguay was likely to supply its own pip-fruit market and compete with New Zealand prospects there, Tacon stated in his 1915 report FruitMarkets and Fruitgrowing in South America that "Uruguay is not, and seems never likely to be, a fruitgrowing country" 246 . By their own admission, Uruguayans recognized that apple trees in their country had to struggle against harmful insects and that entire orchards had been wiped out. But with perseverance and the eventual introduction about 1911 of the Araucano apple tree, which resisted plant louse, it was believed that commercial apple-growing could develop in the country ${ }^{247}$.

In 1912, accordingly, the New Zealand High Commissioner in London, Thomas Mackenzie, visited Montevideo, after which fruit trees from New Zealand were imported into Uruguay. During 1913, following an order from the Dirección General de Agricultura y Defensa Agrícola, fruit trees arrived on the Paparoa (numbering 6,056 plants) and the Corinthia. The fruit trees caused interest in Uruguay for their careful selection and transportation. New Zealand was thought to be a good choice of country from which to obtain the trees because of the select types of fruit it had and the fact that Uruguay and New Zealand shared similar seasons; this had allowed the trees to be uprooted and transported in the same season ${ }^{248}$.

The Styx Apple Company in Canterbury exported apples and pears to Montevideo in 1894-1896, and there was talk at the time of extending the trade to elsewhere in South America and of including quinces ${ }^{249}$. However, in 1910-1912 apples and pears worth $£ 1,427$ were sent again to Uruguay, and after New Zealand fruitgrowers had been briefed by Mackenzie, the exports jumped to the value of $£ 3,941$ in 1913 and $£ 8,994$ in $1914^{250}$.

The first shipment to South America of the 1914 season was made in late February 1914. New Zealand apples were soon being advertised in Montevideo by Miles and Company, a wholesale buying agency business, as "fresh, juicy and rosy" at three pesos a case holding 140 to 160 apples. The managing director, H.J. Miles, had visited New Zealand in 1914 to oversee and inspect apple purchases on behalf of his firm ${ }^{251}$. Unfortunately, the condition and quality of some apples were found to be spoilt on arrival in Montevideo. A number of "unscrupulous growers" had wrongly graded apples, included inferior apples below and above good apples, and carelessly packed them in cases. Some varieties were still green. And others had arrived over-ripe or rotten and had to be thrown over board into the harbour. Miles and Company consequently incurred a loss of over $£ 4,000$ and stopped doing business in New Zealand apples. Tacon wrote

246 Tacon, op. cit., 20.

247 Ramos Montero, op. cit., 586.

248 Press, 22 March 1913, 8 c; Revista de la Asociación Rural del Uruguay, 10 de octubre de 1913,750 .

249 NZF, March 1896, $102 \mathrm{c}, \mathrm{d}$.

250 New Zealand Statistics, Return Showing the General Exports during the Year 1910, 158; 1911 , $173 ; 1912,177 ; 1913$. Volume 2, 156; 1914. Volume 2, 29-30.

251 Dominion, 24 February 1914, 8 c; MT, 8 May 1914, 2 c; 16 May 1914, 9 b; Tacon, op. cit., $10-11$. 
"[b]ad quality debarred J.G. Moore and Company [in Buenos Aires] and Miles and Company from enforcing their clients to take quantities at prices contracted; and owing to money stringency, said clients took full advantage of their opportunity and repudiated agreements made. Had quality been nearly up to standard neither Moore and Co nor Miles and Co need have incurred loss" 252 .

\section{DISCUSSION}

The culture of the Southern Cone was alien to New Zealanders, but the demands and challenges were not. The demands and challenges they faced to the north of the Southern Cone, on the other hand, were unfamiliar, daunting and dangerous. Those few who are known to have ventured to the north of the Southern Cone did so as missionaries in Bolivia, miners also in Bolivia as well as Colombia, an engineer in Peru, a rancher and a planter in Mexico, idealists in the New Australia colony in Paraguay, and as adventurers and mercenaries in Central America, Venezuela and Mexico ${ }^{253}$. On several occasions, countries to the north initiated contact with New Zealand. Between 1879 and 1882 Peruvian ships from Supe and Chimbote on the Pacific coast of Peru entered Lyttelton Harbour in the South Island carrying sugar and returned to Peru with wheat, oats, oatmeal, cheese, butter, stone and samples, suggesting a burgeoning trade between Canterbury and the coastal region of Peru thus seemed possible ${ }^{254}$. Similarly, the first ship to come from Costa Rica sailed into Auckland in 1862 carrying sacks of coffee and flasks of quicksilver, with an intermittent contact continued between the South Island and Costa Rica in later years ${ }^{255}$. In the final analysis, however, connections between New Zealand and the republics to the north of the Southern Cone were slight. From 1906 articles such as panama hats and coffee and cocoa beans began to arrive in New Zealand from Peru, Mexico, Guatemala, Ecuador and Venezuela. In 1914,

252 Tacon, op. cit., 9, 11.

253 Southland Times, 5 August 1892, 2 g; 8 March 1935, 12 e; Press, 5 August 1892, 5 e; 2 August 1893, 4 d, e; 30 August 1909, 6 e, f; 21 March 1911, 6 e; 24 August 1912, 8 b, c; 17 March 1911, 8 c; EP, 27 August 1909, 3 b; 26 March 1910, 15 c; 23 December 1911, 4 d; 2 July 1912, 3 d; Dominion, 1 August 1914, 6 c; TNZMR 8:4, 16 November 1904, 151; 9:6, 16 January 1905, 247, 9:8, 16 March 1906, 343; [The Cyclopedia of New Zealand Company], "Leslie Hunter Reynolds", The Cyclopedia of New Zealand. Volume 4: Otago and Southland Provincial Districts, Christchurch, The Cyclopedia Company, 1905, 288-289; Otago Boys' High School Old Boys' Register, op. cit., 5; Compton, op . cit., 39; Hudspith, op. cit., 27-28, 34; Gavin Souter, A Peculiar People: the Australians in Paraguay, Sydney, Angus and Robertson, 1968, 4, 10, 16-19, 117, 167, 180, 186, 211, 220, 283285, 288; Paul Freyberg, Bernard Freyberg, VC, London, Hodder and Stoughton, 1991, 29-33; Hugh Morrison, "We Carry the Joyous News that has Made Us Free', New Zealand Missionaries, the Bolivian Indian Mission and Global Engagement, 1908-1930", New Zealand Journal of History 39:1, Auckland, 2005, 42 .

254 Press, 7 November 1878, 2 a; 12 December 1878, 2 a; 16 June 1879, 2 a; 31 October 1879, 2 a; 27 November 1879, 2 b; 14 December 1879, 2 a; 7 March 1882, 2 a.

255 Daily Southern Cross, 12 December 1862, 3 a; 13 December 1862, 3 a; Australasian Insurance and Banking Record 13:12, Melbourne, 1889, 971; New Zealand Statistics, Return Showing the General Imports during the Year 1895, 132; 1896, 138 (dried and preserved fruit); Return Showing the General Exports from the Colony of New Zealand during 1906, 255 (agricultural machinery). 
too, the range markedly broadened both in terms of countries and goods coming into New Zealand after a distinction was made between "country of origin" and "country whence imported" following a revision to Customs Regulations. The country of shipment had been hiding the country of origin of incoming articles, and at least one observer believes New Zealand's actual purchases from Central and South America had been disguised ${ }^{256}$.

And while ships from New Zealand went to Callao, the port played a secondary role to Valparaíso. Even the Panama Isthmus crossing -a railway corridor of some 77 kilometres situated between Panama City on the Pacific side and Colon in the Caribbean- used by travellers to and from New Zealand, was "a pleasure trip" for them ${ }^{257}$. Colombia, Nicaragua, Honduras, Paraguay, Mexico and Peru had consular representation in New Zealand at one time or another after 1886 , but by all accounts more nominal than operative ${ }^{258}$.

Instead, the basis of New Zealand's relationship with Latin America between 1820 and 1914 was its focus on the Southern Cone countries. New Zealand's association with them was connected to New Zealand's processes of colonization and recolonization. When New Zealand as a British colony and Dominion did not have its own dialogue with Latin America and there was little sign of any autonomous trajectory, the presence of the British in Latin America and their networks laid the ground for New Zealand's relationship. The already-established British community in the Southern Cone opened the way for New Zealanders into the otherwise foreign world of Latin America. Engagement was further buttressed by a worldview shaped by Anglo-Saxonism, an ideology which itself shifted in the course of the relationship from an emphasis on the differences between Spanish, Latin American and British institutions in the mid 1840s to a fascination with racial compositions of Latin Americans by the mid 1860s.

The British World in Latin America therefore expanded New Zealand's own geographic presence. The interaction went further than ships calling into ports of call during their voyages between New Zealand and Britain. Trade was seen as a possibility and one in which South Americans themselves expressed interest ${ }^{259}$. As early as 1889 the Christchurch Press asked whether New Zealand could start

256 New Zealand Statistics, Return Showing the General Imports during the Year 1906, 205; 1907, $176 ; 1908,98 ; 1910,56,74 ; 1911,58,85 ; 1912,128 ; 1914,169,184-185,191,210,213,232,249$, 320, 334, 352, 355, 356, 365; New Zealand Official Year-Book 1914, Wellington, Government Printer, 1914, 381; Prendergast, op. cit., 430.

257 Daily Southern Cross, 24 November 1865, 6 e.

258 New Zealand Statistics, Foreign Consuls, Colombia (represented from Melbourne): 1886, 13; 1887,$13 ; 1888,13 ; 1889,13 ; 1890,13 ; 1891,13$; Nicaragua (from Sydney): 1893, 13; 1895, 14; 1896, 15; Honduras (from Sydney): 1906, 17; 1908, 16; 1909, 17-18; 1910, 17-18; 1911, 17-18; 1912, 18-20; 1913, 19-20; 1914, 16-18; Appointment of Paraguayan Consuls at Wellington 1906-1934, Series EA 1 61/394/2 pt 1, Ministry of Foreign Affairs and Trade papers, Archives New Zealand, Wellington; Appointment of Mexican Consuls at Auckland 1907-1925, Series EA 1 61/407/1 pt 1, Ministry of Foreign Affairs and Trade papers, Archives New Zealand, Wellington; Peru General 1911-1941, Series EA $161 / 417 / 1$ Pt 1a, Ministry of Foreign Affairs and Trade papers, Archives New Zealand, Wellington.

259 Chile Austral, 18 de enero de 1911, 5 c. 
trading its own pedigree sheep and cattle to South America in view of the ready demand, particularly in Argentina ${ }^{260}$. And while New Zealand eventually exported animals and agricultural knowledge to the Río de la Plata and Southern Patagonia despite the possibility of competition, the pay-off was New Zealand's access to South America with a significant trade with Uruguay and a demand for fresh apples in the Plata region and the potential for expansion of trading links.

Connections between New Zealand and the Southern Cone diminished after 1914, although they never disappeared. After the First World War, for example, the export of New Zealand apples and sheep to Argentina and Uruguay resumed, while people making visits maintained business and agricultural links in particular. The present New Zealand process of strengthening its relationship with Latin America arguably had its origins in the sale of milk products to Chile in 1971, the appointment of New Zealand trade commissioners to Peru and Chile in 1972, and the New Zealand government's Puno aid project in the Peruvian altiplano in 1974. It has been slow as New Zealanders have been learning to interrelate with Latin Americans for the first time on their own terms, unaffiliated to an Empire and other mindsets.

260 Press, 13 September 1889, 2 e, f. 